\title{
The age of mass migration in Latin America $^{\dagger}$
}

\author{
By BLANCA SÁNCHEZ-ALONSO iD*
}

\begin{abstract}
The experiences of Latin American countries are not fully incorporated into current debates concerning the age of mass migration, even though 13 million Europeans migrated to the region between 1870 and 1930. This survey draws together different aspects of the Latin America immigration experience. Its main objective is to rethink the role of European migration to the region, addressing several major questions in the economics of migration: whether immigrants were positively selected from their sending countries, how immigrants assimilated into the host economies, the role of immigration policies, and the long-run effects of immigration. Immigrants came from the economically backward areas of southern and eastern Europe, yet their adjustment to the host labour markets in Latin America seems to have been successful. The possibility of rapid social upgrading made Latin America attractive for European immigrants. Migrants were positively selected from origin according to literacy. The most revealing aspect of new research is showing the positive long-run effects that European immigrants had in Latin American countries. The political economy of immigration policies deserves new research, particularly for Brazil and Cuba. The case of Argentina shows a more complex scenario than the classic representation of landowners constantly supporting an open-door policy.
\end{abstract}

$\mathrm{L}$

atin America was considered a 'land of opportunity' from 1870 to 1930 and 13 million Europeans migrated to the region in that period. Historians have frequently called for a comparative approach in immigration studies, but research on Latin American countries lags behind that on other New World countries. ${ }^{1}$ Textbooks on long-run economic growth or the economic history of Latin America concentrate on trade and capital and, surprisingly, devote few pages to the performance of Latin American countries in international labour markets. ${ }^{2}$

A major shift has occurred in Latin America since the 1960s with the transformation of the region from a major migrant destination to a major source of migrants. This change made research on historical immigration the domain of historians and sociologists focused on topics such as residential segregation, marriage patterns, and ethnic communities. Since large-scale international immigration stopped after the 1930s, few studies have considered the long-term effects of European immigration within Latin America. This contrasts with the

\footnotetext{
*Author's Affiliation: Universidad San Pablo-CEU.

${ }^{\dagger}$ This article benefited greatly from discussions over the years with Timothy J. Hatton and Jeffrey G. Williamson. I gratefully acknowledge comments and suggestions by Jaime Reis, Herbert Klein, and participants of the Economic History Seminars at Oxford and the London School of Economics. Four anonymous referees and the editors of this journal contributed very helpful comments. The usual disclaimer applies.

${ }^{1}$ An example of an effort to integrate non-English-speaking countries is Hatton and Williamson, Age of mass migration.

${ }^{2}$ Bulmer-Thomas, Economic history of Latin America; Bértola and Ocampo, Economic development. 
long immigration experience of the US over the last two centuries which has allowed researchers to connect history with current debates on immigration. Until recently, the Latin American migratory experience has had only a limited impact in debates on the consequences of migration compared with the experiences of other countries. The revival of research on immigrants in Latin America can be seen as an unintended consequence of recent research on the long-run impact of European settlement on current levels of development in the world. A new generation of research is now addressing old questions, such as immigrants' occupational upgrading and performance in the labour market, with new data and methodologies.

The main objective of this survey is to rethink the role of European migration to the region. It is not limited to the cliometrics approach, and research by historians and social scientists will be frequently used. ${ }^{3}$ It addresses several major questions in the economics of migration: whether immigrants were positively selected from their sending countries, how immigrants assimilated into host economies, the role of immigration policies, and the long-run effects of immigration in Latin America.

This survey is organized as follows. Section I presents the main trends of migration to Latin America, the origins and destinations of migrants, and also discusses return migration. This section reflects on whether returnees were successful target earners or those negatively selected who failed to adapt in their host countries. Section II discusses the reasons why European emigrants selected Latin American destinations, focusing on real wage differentials, language, and cultural affinity. This section presents arguments that encourage us to rethink the Lewis model of elastic labour supply when applied to Latin American flows. Section III focuses on immigration policies, particularly the long-lasting programme of subsidized immigration to Brazil and on some peculiarities of Argentine immigration policy. Section IV analyses immigrant adjustment to Latin American labour markets, and considers occupational upgrading and whether southern European emigrants to the region were positively selected according to literacy. Section $\mathrm{V}$ deals with the long-run effects of immigration to Latin America and highlights new research that shows the positive impacts of European immigrants on human capital accumulation. A final section summarizes the main findings of this survey and suggests areas for new research.

\section{I}

About 60 million Europeans migrated to the New World; these were economies characterized by capital and labour scarcity and an abundance of land. Ferenczi and Willcox documented the main trends in international migration (figure 1). ${ }^{4}$ Until the last quarter of the nineteenth century Latin America remained marginal to the international market for free labour and the later flows were lower than those to North America. ${ }^{5}$ Table 1 presents immigration rates for the main destinations.

\footnotetext{
${ }^{3}$ See Hatton, 'Cliometrics'.

${ }^{4}$ Ferenczi and Willcox, International migrations.

${ }^{5}$ The distinction between free and coerced labour is important. Latin America was a major participant in the Atlantic slave trade; Klein, Atlantic slave trade; Eltis, 'Free and coerced'. Forced migration, however, will not be addressed here.
} 


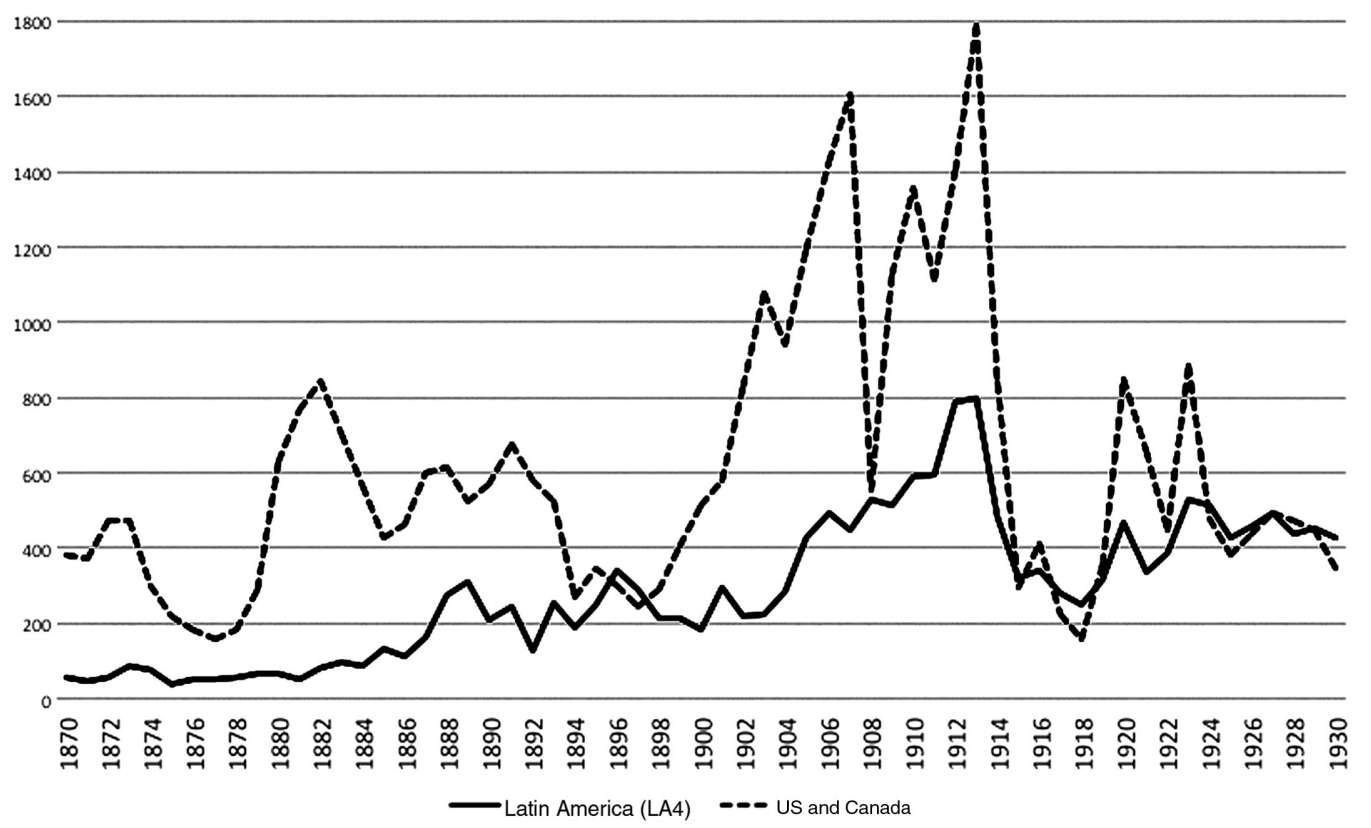

Figure 1. Immigration to Latin American countries and North America (000s), 18701930

Note: LA4 = Argentina, Brazil, Cuba, and Uruguay.

Sources: Ferenczi and Willcox, International migrations. Cuba: 1870-1900, Spanish immigration only from Yañez, Emigración española. Canada: Statistics Canada, 150 Years. Uruguay: Nahum, ed., Estadísticas históricas, vol. I, pp. 9, 31.

Table 1. New World immigration rates by decade (per thousand people)

\begin{tabular}{lrrrrr}
\hline & $1861-70$ & $1871-80$ & $1881-90$ & $1891-1900$ & $1901-10$ \\
\hline Argentina & 99.1 & 117.0 & 221.7 & 163.9 & 291.8 \\
Brazil & & 20.4 & 41.1 & 72.3 & 33.4 \\
Cuba & & & 118.3 & $88.0^{a}$ & 118.4 \\
Uruguay & 122.2 & 100.4 & 146.9 & 7.3 & 9.9 \\
Australia & 83.2 & 54.8 & 78.4 & 48.8 & 167.6 \\
Canada & 64.9 & 54.6 & 85.8 & 53.0 & 102.0 \\
US & & &
\end{tabular}

Note: a $1893-1900$.

Sources: Williamson, 'Real wages inequality', p. 129. For Uruguay, Ferenczi and Willcox, International migrations, vol. I, pp. 566-7; Nahum, ed., Estadísticas históricas, vol. I, pp. 9, 31; Instituto Panamericano de Geografía e Historia, Inmigración y estadísticas, pp. 285-92.

The ability of Argentina to attract large numbers of immigrants relative to its own population is remarkable. In 1910-14 foreigners represented 14.5 per cent of the total population in the US but around 30 per cent in Argentina.

Civil wars in the Southern Cone, slavery in Brazil and Cuba, and the tyranny of distance for Chile and Peru prevented a high flow of immigrants being attracted to the area before the 1870 s. Various colonization projects brought Europeans to 
some countries in the mid-nineteenth century, but most plans failed miserably. ${ }^{6}$ The German colonies were more successful than those of other nations in southern Brazil and Chile. Italians contributed to successful colonies in Argentina and Brazil and, in the early period, Portuguese immigration to Brazil was also significant. Only a few countries in Latin America managed to attract massive European immigration from 1870 onwards. More than 90 per cent of the European emigrants who travelled to the region between 1870 and 1930 chose Argentina, Brazil, Uruguay, or Cuba. From the mid-nineteenth century until 1930 approximately four million Europeans settled in Argentina, some two million in Brazil, and slightly fewer than 600,000 in each of Cuba and Uruguay. ${ }^{7}$ European countries were not the only sources of migration into Latin America. Chinese coolies were employed in Peru, in the sugar plantations of Cuba and the Caribbean, and in railway construction in some Central American countries. After 1907 the state of São Paulo became a major destination for Japanese immigration. ${ }^{8}$ In this period the British, French, and Dutch plantation economies in the Caribbean found their supply of labour in British India or in the Dutch colonies in Asia. The arrival of Asians and Chinese bound to servitude in the Caribbean had very different implications from the arrival of free Europeans, but these migrations were driven by the same underlying economic forces. ${ }^{9}$ Immigration from Asia was not massive compared with the European stream but in the century up to 1916 around 700,000 indentured labourers were transported to the region. ${ }^{10}$

European sources of migrants changed over time. A country's 'emigration life cycle' related to demographic transition, industrialization, and the 'pull' of growing stocks of migrants abroad has been well documented. ${ }^{11}$ Emigrants from southern and eastern Europe account for most of the surge in numbers from the 1880s, but Italians and Portuguese were relatively early migrants in Latin America. Emigrants from eastern Europe began to arrive in the late 1890s, while those from the former Ottoman Empire did so during the 1920s. For the whole region, there was a high concentration of immigrants in the decades prior to the First World War. More than half a million Spanish immigrants disembarked in Buenos Aires in 1910-13, surpassing the number of those who had arrived in Spanish America during more than three centuries of colonial rule. ${ }^{12}$ The era of mass immigration was shortlived; after 1914, the rate of immigration fell, and the Great Depression signalled the end of mass migration to Latin America. ${ }^{13}$

In Latin America the composition of immigrants remained stable over time. Figures 2 and 3 for Argentina and Brazil show a constant and large share of southern European immigrants. Cuba mainly received immigrants from Spain and in 1908, 87 per cent of foreigners living in Uruguay were Italians and Spaniards. European migrants were predominantly male and travelled alone, although Brazil showed greater immigration of families.

\footnotetext{
${ }^{6}$ For example, in Paraguay; Frezt, Immigrant group settlement.

7 Sánchez-Albornoz, Population, p. 129.

${ }^{8}$ Masterson, Fapanese.

${ }^{9}$ Hatton and Williamson, Global migration, ch. 7; McKeown, 'Global migration'.

${ }^{10}$ Emmer, 'Immigration', tab. 11.1; Bulmer-Thomas, Economic history of the Caribbean, ch. 3.

${ }^{11}$ Hatton and Williamson, Age of mass migration, ch. 3.

${ }^{12}$ Martinez Shaw, Emigración, pp. 152, 167, estimates 470,000 arrivals in the entire colonial era.

${ }^{13} \mathrm{Cuba}$ is the main exception to the downward trend of the 1920 s due to the sugar boom.
} 


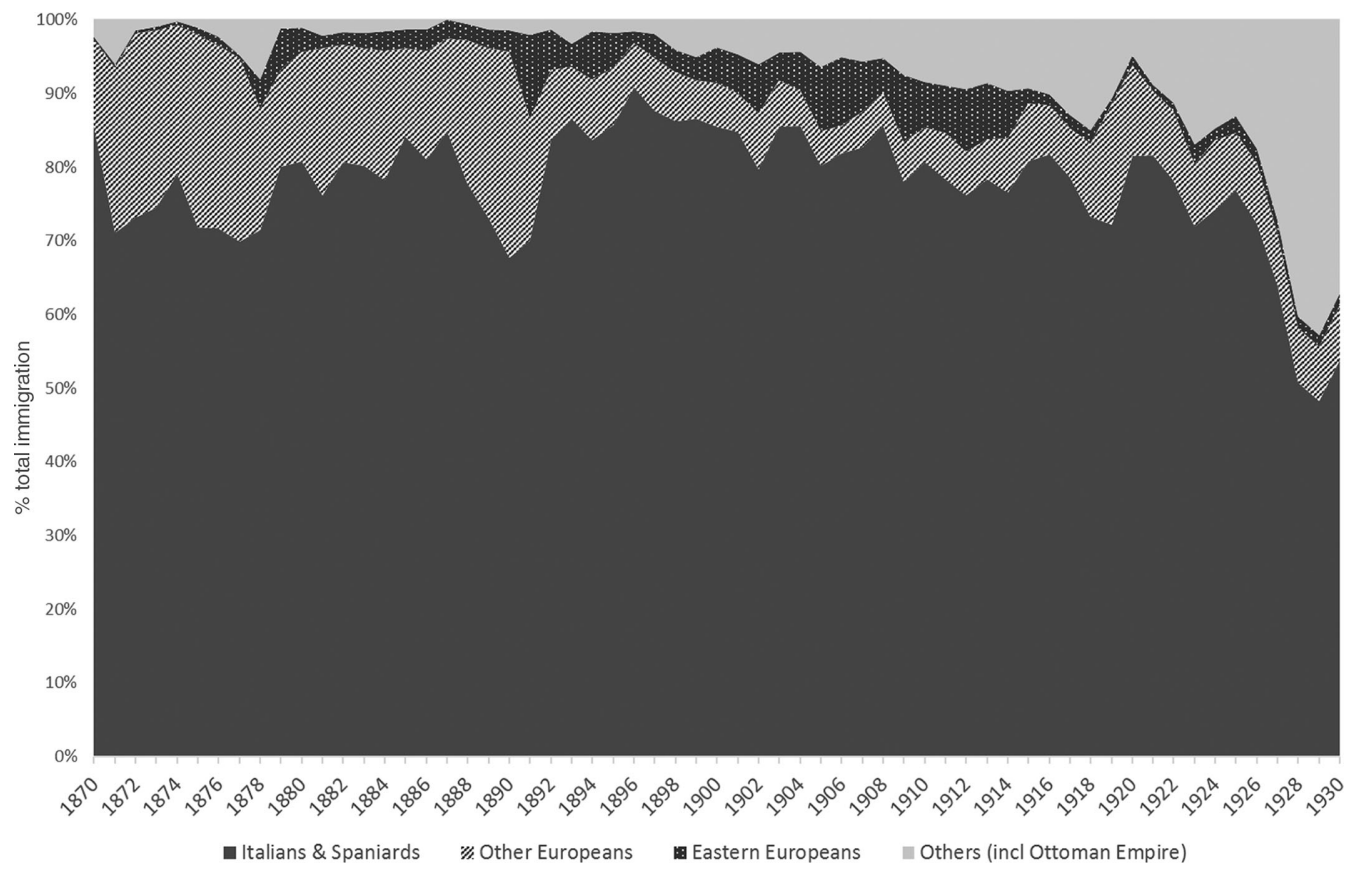

Figure 2. Argentina: immigration composition by origin, 1870-1930 (main groups) Source: Sánchez-Alonso, 'Making sense', p. 610.

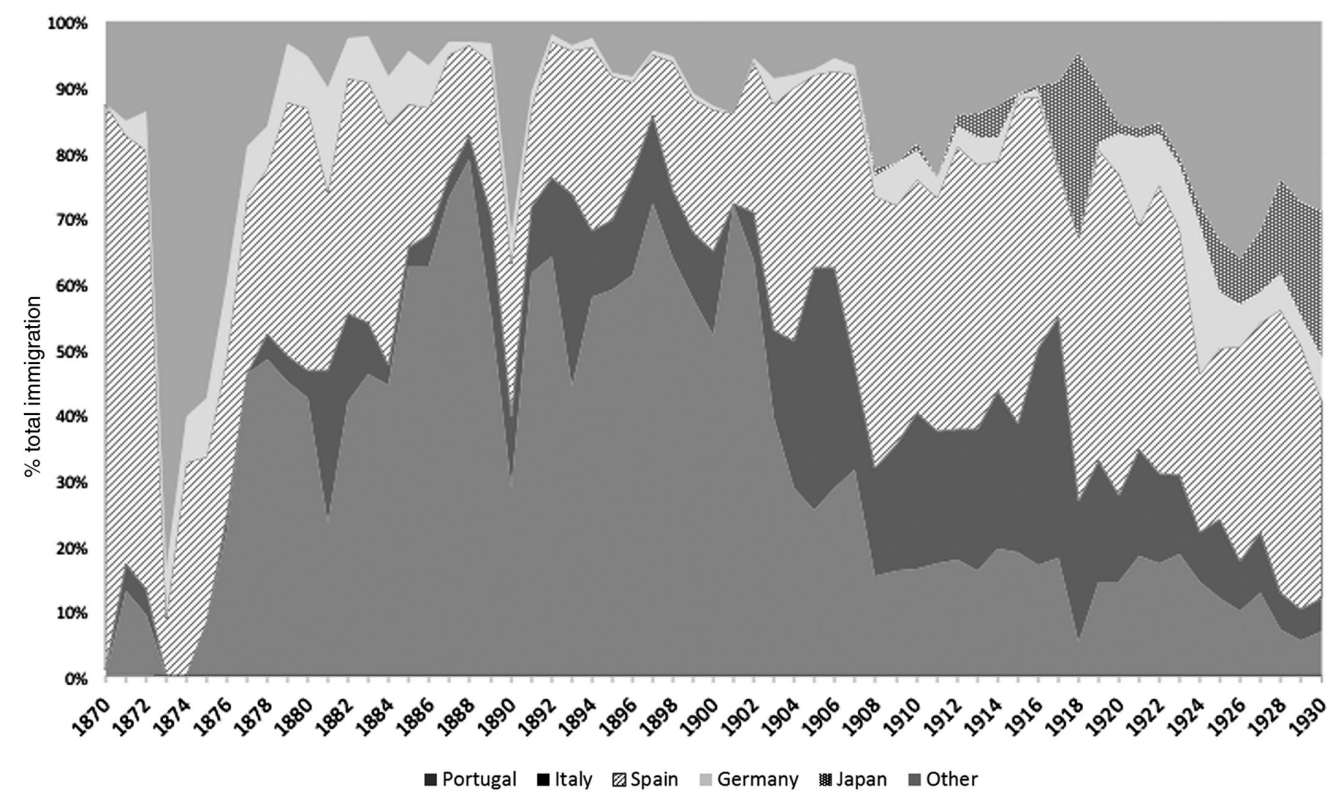

Figure 3. Brazil: immigration composition by origin, 1870-1930 (main groups) Source: Klein, Inmigración Española, app., pp. 143-7. 


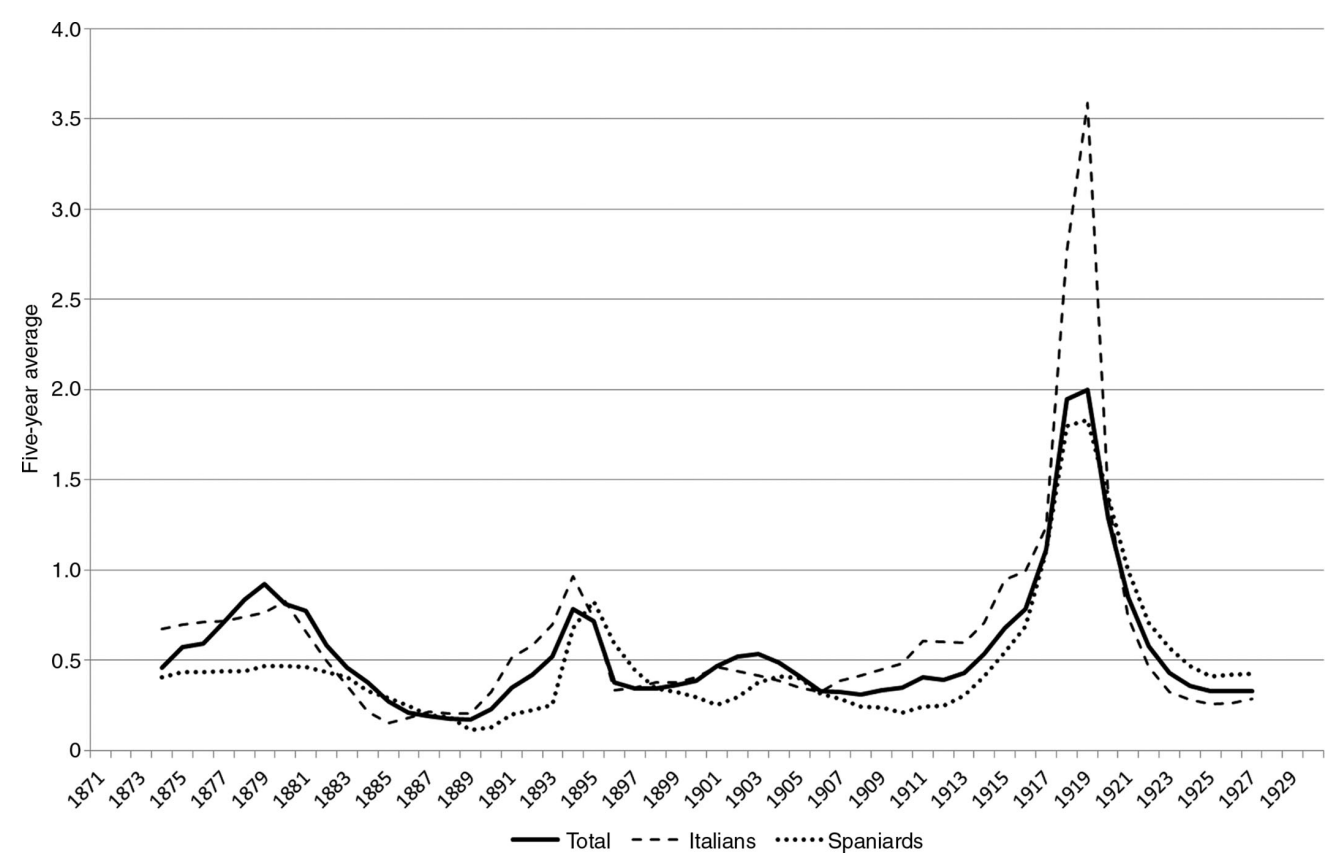

Figure 4. Ratio of returns to arrivals: Argentina, 1870-1927

Source: Dirección General de Inmigración, Resumen estadístico, pp. 8-9.

Return migration was high, but not substantially different to that of the same nationalities returning from the US. ${ }^{14}$ Figure 4 presents fluctuations in return migration from Argentina according to official statistics. Italians seemed readier to abandon the country than Spaniards and all immigrants together, particularly in the early 1890 s and 1914-19. There is a clear upward trend for all migrants starting in 1900. The rising trend in return migration is related to reduced journey time. On the River Plate route from Spanish ports, steamers cut the trip from around 55 days in the mid-nineteenth century to just 12 days in the 1910s.

Unfortunately, Brazilian return data are fragmentary and refer to passengers' departures from the port of Santos from 1892. Based on the growth of the foreign population in Brazil, Ferreira Levy estimated a rate of return of 46 per cent of arrivals, with Italians showing the highest repatriation rate, followed by Spaniards, the Portuguese, and the Japanese. ${ }^{15}$ Yañez calculates a 47 per cent global return rate to Spain from America in 1870-1930, with the lowest value from Argentina and the highest from Cuba because of seasonal migration during the $1920 \mathrm{~s}^{16}$ It may be misleading to assume that return migrants only returned to Europe. Many immigrants moved frequently between Argentina, Uruguay, and Brazil.

\footnotetext{
${ }^{14}$ Recently, Bandiera, Rasul, and Viarengo, 'Modern America', estimated that $60-75 \%$ of migrants returned to Europe from the US in the 1900s and 1910s. These figures are over twice as high as official estimates.

${ }^{15}$ Ferreira Levy, 'O papel', p. 66. There was hardly any return migration among the Chinese in the Caribbean.

${ }^{16}$ Yañez, Emigración, pp. 135-7. The comparison of out-migration rates based on the official statistics ignores mortality and is purely derived from counts of migrant inflows and outflows.
} 
Yañez estimates that 26 per cent of Spaniards leaving Argentina in the years 1894-6 moved to Brazil. Re-emigration from São Paulo to Argentina when coffee contracts ended was also frequent. ${ }^{17}$

Return migration may have been planned as part of an optimal life-cycle residential location sequence: target-income immigrants migrate for a few years, accumulate financial resources, and then return to their source country. If immigrants planned to return after reaching target savings, success in the host labour market implied returning home. Therefore, conceptually, return migrants could be positively selected if more productive migrants reached their target savings faster than others. Alternatively, migrants may have returned at particular times due to unexpected changes in the economic situation of the destination or origin country. The high return rate of migrants of all nationalities from Argentina after the 1890 Baring Crisis was an immediate reaction to the steep decline in workers' living standards and distress in the urban labour market. This crisis could have pushed out many target income immigrants early. Or, alternatively, immigrants may have remained to compensate for lower wages in the host country simply by staying longer. ${ }^{18} \mathrm{~A}$ third possibility for return migration is that immigrants failed to adapt to the host country. Return migrants may have been negatively selected because those who were unsuccessful returned home. ${ }^{19}$ This seems to be the case for the high level of out-migration from Argentina in the early 1890s. Since there had been a policy of subsidized immigration for the three preceding years, Argentine immigration officials estimated that two-thirds of these subsidized immigrants were negatively selected because of their lack of skills. ${ }^{20}$ It is therefore possible that a share of immigrants leaving Argentina after the Baring Crisis had been negatively selected by subsidized passages and subsequently failed to adapt. This implies a possible bias in the cross-section analysis on earnings and occupation for the census year of 1895 (see section IV).

With the available evidence we cannot assume either positive or negative selection in return migrations because no relevant data on the characteristics of returned migrants exist. For Italian migration, however, there is a consensus that return migration was not the result of failure since it was part of a lifetime strategy for improving living standards at home. ${ }^{21}$ As the return rates from the US, Brazil, and Argentina were all similarly high, it seems unlikely that Italians were unsuccessful in all these destinations. But nothing conclusive can be said about returns to Spain or Portugal. These communities showed the lowest return rate from both Argentina and Brazil, but the evidence is at best fragmentary about whether this indicates positive or negative selection into return migration.

Latin America entered the age of mass migration late in the nineteenth century. The migratory boom was concentrated in 1900-14 with only a modest revival in 1920 (except in Cuba). Immigrants came overwhelmingly from southern Europe and re-emigration and return migration was high.

\footnotetext{
${ }^{17}$ Ibid., tab. 17; Holloway, Immigrants, p. 95.

${ }^{18}$ Dustmann, 'Return migration'.

${ }_{19}$ Abramitzky, Boustan, and Eriksson, 'Nation of immigrants'.

${ }^{20}$ República Argentina, Memoria, p. 55.

${ }^{21}$ More than $75 \%$ of Italians applying for a passport after 1901 declared their intention to return regardless of their destination; Cinel, From Italy, pp. 47-9.
} 
Table 2. Relative real wages (PPP-adjusted), Europeldestination countries

\begin{tabular}{lccccccc}
\hline & \multicolumn{3}{c}{$1870 / 4$} & & \multicolumn{3}{c}{$1909 / 13$} \\
\cline { 2 - 3 } & Argentina $=1$ & $\begin{array}{c}\text { South-east } \\
\text { Brazil }=1\end{array}$ & US $=1$ & & Argentina $=1$ & $\begin{array}{c}\text { South-east } \\
\text { Brazil=1 }\end{array}$ & US $=1$ \\
\hline Germany & 1.06 & 1.67 & 0.51 & & 0.94 & 1.31 & 0.52 \\
Britain & 1.15 & 1.80 & 0.55 & & 1.02 & 1.42 & 0.57 \\
Ireland & 0.86 & 1.35 & 0.41 & & 0.97 & 1.35 & 0.54 \\
Scandinavia & 0.65 & 1.02 & 0.31 & & 1.04 & 1.44 & 0.57 \\
Southern Europe & 0.45 & 0.70 & 0.21 & & 0.48 & 0.66 & 0.26 \\
\hline
\end{tabular}

Notes: Williamson's real wage estimates for south-east Brazil have been revised upwards with the Brazil-Argentina real wage ratio for 1913 in Astorga, 'Real wages', relative to the same ratio in Williamson, 'Real wages and relative factor prices'. Astorga computed purchasing power parity (PPP)-adjusted unskilled wages at 1970 prices for Brazil and Argentina for 1913, while Williamson simply derived PPP-adjusted wages for Brazil in 1913 by assuming that the ratio of real unskilled wages between Brazil and Argentina was identical to that of GDP per capita using Astorga and Fitzgerald, 'Standard of living'.

Sources: For south-east Brazil: Williamson, 'Real wages and relative factor prices'. Other countries: idem, 'Evolution of global labor markets' (updated appendix).

\section{II}

A potential European emigrant could choose between alternative destinations within America in the late nineteenth century. However, attempts to explain the choice between competing destinations using formal economic models of migration have not been very illuminating. For Italy, Hatton and Williamson found that the choice between Latin America and the US was mainly driven by the stock of previous emigrants, a finding confirmed by Gomellini and Ó Gráda. ${ }^{22}$ Balderas and Greenwood find little evidence of substitution between Argentina and Brazil for 12 European countries; a surprising result since, once arrived, immigrants moved frequently between these two countries. ${ }^{23}$

Economists assume that wage differentials between home and destination are the fundamental cause of migration. Research by Williamson documents levels and trends in real annual wages for many countries from $1870 .{ }^{24}$ Williamson's data suggest that during the years of massive European migration, Latin American countries could not compete for labour by offering wages at US levels. The relevant question, then, is why not all European migrants maximized the wage gap between home and destination by going to the US. A glance at table 2 helps to understand why neither British nor German emigrants chose Argentina or Brazil, but it is difficult to explain why all southern Europeans did not migrate to the US. Italian unskilled wages in the 1870 s were 43 per cent of those in Argentina and 22 per cent of those in the US. However, in the 1870s and 1880s most Italian emigrants went to Argentina. ${ }^{25}$

To explain the destination selected, the literature has considered, among other variables, language and cultural affinity. The transoceanic migrants from Europe sought to minimize the loss of language capital, with those moving to South America more likely to come from Romance language countries, while those from

\footnotetext{
${ }^{22}$ Hatton and Williamson, Mass migration; Gomellini and Ó Gráda, 'Migrations'.

${ }^{23}$ Balderas and Greenwood, 'Europe to the Americas'. Hatton and Williamson, Mass migration, tab. 6.9, found a strong substitution effect for Italian immigrants.

${ }^{24}$ Williamson, 'Real wages inequality'. Data refer to urban unskilled wages.

${ }^{25}$ Devoto, Historia de los italianos.
} 
the British Isles favoured North America. ${ }^{26}$ It is often suggested that colonial ties and cultural affinity meant that different destinations were poor substitutes, a feature reinforced by the friends and relatives effect. For Spain and Portugal, selecting Latin American destinations allowed immigrants to enjoy advantages in the commercial sector due to language and old colonial links. ${ }^{27}$ Colonial ties and the complex, long-standing trade and mercantile relationships of the Portuguese with Brazil, and Spaniards with Cuba, help to explain why immigrants concentrated in commercial cities such as Rio de Janeiro or Havana. For example, the high proportion of Spanish-born bank clerks in Cuba in 1907 (57 per cent) reflects the weight of Spanish banks in the island before Independence. ${ }^{28}$ In Buenos Aires, Spanish male workers dominated sales occupations. Knowledge of the language appears to have been an asset for the choice of occupation. Unskilled labour commanded higher wages in the US and language was less of an impediment for unskilled employment. Less skilled and more rural southern Italian immigrants chose the US over Latin America from the late nineteenth century. In contrast, skilled northern Italians moved easily into commerce and business in Argentina. Skilled northern Portuguese workers chose Brazil while unskilled emigrants from the Azores went to the US. ${ }^{29}$ Human capital is more easily transferred between countries sharing the same (or a similar) language.

The wage hierarchy within Latin America shows that other countries found it hard to compete with the River Plate. Argentina and Uruguay display the highest wage levels up to 1914; therefore, migrants flowed in higher numbers to the River Plate than to Brazil or Cuba. Wages in Argentina and Uruguay were consistently much higher than in southern Europe (figure 5). Recent data show that in Argentina there was a rising trend in wage skill premiums from 1900 to the early $1930 \mathrm{~s}^{30}$

Brazil, however, presents a puzzle for the traditional explanation of migration based on real wage gaps; unskilled wages were higher than the average wage levels in southern European countries but not as much as in the River Plate. Nevertheless, between 1870 and 1940, approximately four million European immigrants, mainly from southern Europe, entered Brazil. Focusing only on real wages suggests that southern European emigrants might have selected the 'wrong' country. The Todaro model explains that the migration decision is based on future expected income at home and abroad rather than wage differentials alone. ${ }^{31}$ The expected income of immigrants to São Paulo was augmented by prospective savings, a guaranteed job on arrival, and the subsidized transportation cost. ${ }^{32}$ Going to Brazil was perceived as a good investment in southern Europe. ${ }^{33}$ There are two relevant factors in explaining the choice of Brazil as a destination: transport subsidies and colono contracts in the coffee areas.

${ }^{26}$ Chiswick and Hatton, 'International migration'.

27 Taylor, 'Mass migration'.

${ }^{28}$ Maluquer de Motes, Nación. For the Portuguese in Brazil, see Klein, 'Social and economic integration'; Sánchez-Alonso, 'Other Europeans'.

${ }^{29}$ Baganha, 'Migration'.

30 Astorga, 'Real wages'.

31 Todaro, 'Model'

${ }^{32}$ Similarly, Pope, 'Push-pull', stressed that most British emigrants went to Australia because of enhanced employment prospects, not because of better wages.

${ }^{33}$ Newspapers and immigrants' letters stressed the miserable conditions of working in the plantations, but Italians kept travelling even after the ban on subsidized immigration (1902); Franzina, Merica. 


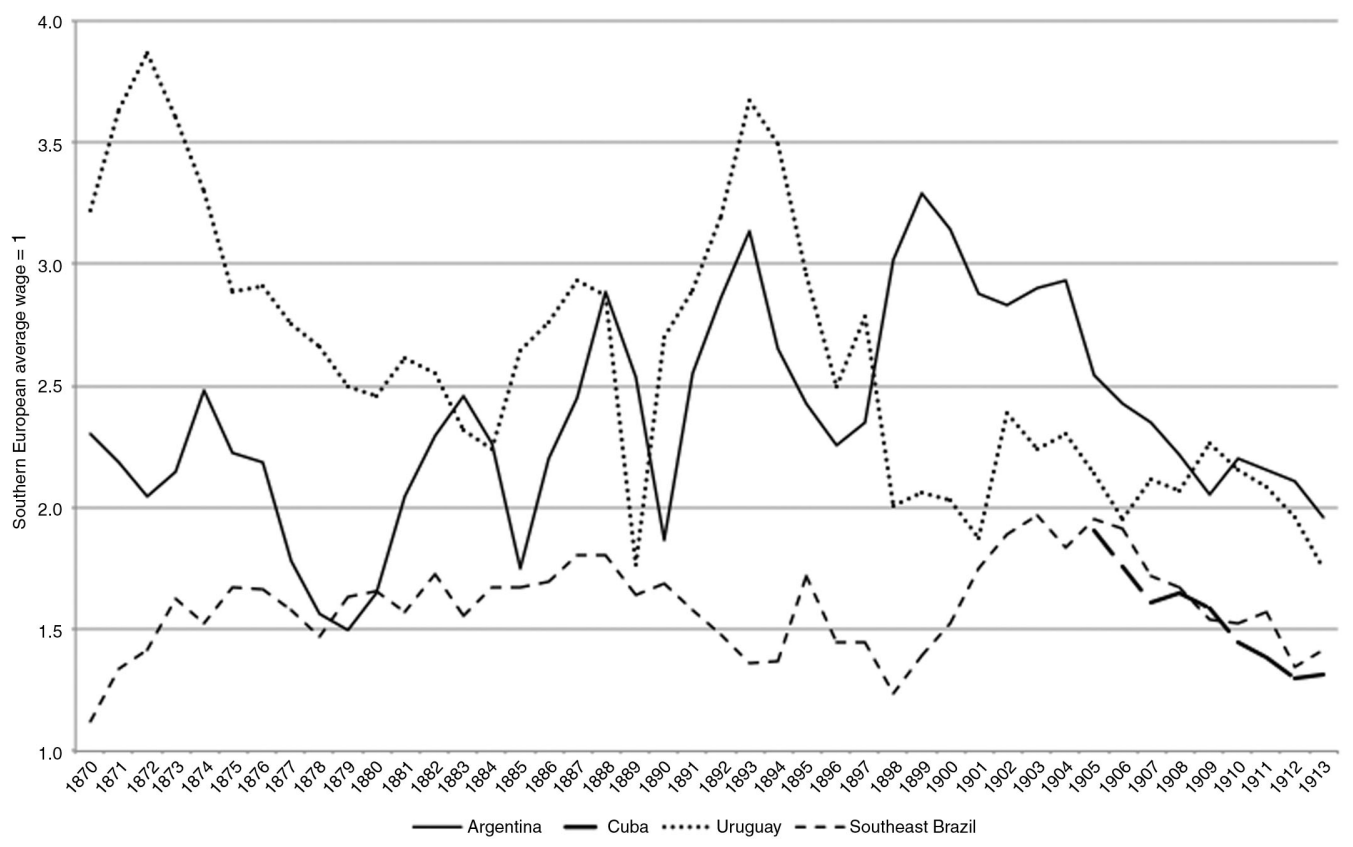

Figure 5. Real wages in Latin America relative to southern European countries, 1880 $1930(\%)$

Notes: Each Latin American country's real wage is reported relative to the average of Italian, Portuguese, and Spanish real wages (weighted by its population in 1913). For each country, purchasing power parity (PPP) real wages are referred to Great Britain in $1913=100$. Williamson's real wage estimates for south-east Brazil have been revised upwards with the Brazil-Argentina real wage ratio for 1913 in Astorga, 'Real wages', relative to the same ratio in Williamson, 'Real wages and relative factor prices'. Astorga computed PPP-adjusted unskilled wages at 1970 prices for Brazil and Argentina for 1913, while Williamson simply derived PPP-adjusted wages for Brazil in 1913 by assuming that that the ratio of real unskilled wages between Brazil and Argentina was identical to that of GDP per capita using Astorga and Fitzgerald, 'Standard of living'. Since Astorga's wages correspond to Brazil and Williamson's to south-east and north-east Brazil, an average of Williamson's regional wages using 1970 population weights (as implicit in Astorga's estimates) was calculated.

Sources: For south-east Brazil, Cuba, and Uruguay: Williamson, 'Real wages and relative factor prices'. For Argentina and southern Europe: idem, 'Evolution of global labor markets- (updated appendix).

Subsidized immigration helped potential emigrants in Europe to overcome the problems involved in funding long-distance migration. ${ }^{34}$ From 1888 to the 1930s more than two million immigrants arrived in São Paulo and around 58 per cent of them were subsidized. ${ }^{35}$ In the nineteenth century Italians predominated, constituting 73 per cent of all arrivals. Spaniards were also among the main beneficiaries of the Brazilian system. In contrast, family connections and longestablished networks explain why the flow of Portuguese occurred without these subsidies. ${ }^{36}$ Trends of Portuguese emigration to Brazil are similar to those of Spain with massive arrivals in the 1890s and in 1904-14. From 1900 to 1930 the nationality distribution became more diverse.

\footnotetext{
${ }^{34}$ Poverty and information constraints explain why emigration was so low from some Spanish provinces despite large wage differentials with the New World; Sánchez-Alonso, 'Those who left'. Faini and Venturini, 'Italian emigration', argued the same for Italy.

${ }^{35}$ Vangelista, Braccia; Holloway, Immigrants.

${ }^{36}$ Klein, 'Social and economic integration'.
} 
However, it is difficult to assess accurately the impact of transport subsidies on potential emigrants. In 1905-13, the cost of the trip to Latin America for an agricultural worker from northern Spain represented 32 per cent of his yearly income, slightly more than for a northern Italian worker (28 per cent). ${ }^{37}$ In the 1880 s, fares to the River Plate from Spain represented 40 per cent of an agricultural worker's annual income. Real wages in the Italian north-east in the $1880 \mathrm{~s}$ and early 1890 s were as low as in the south in the 1900s, but in the 1900s they grew. Thus, subsidies to passage were attractive to potential emigrants from the north-east in the 1880s-1890s but less so in the 1900s. But migrants from the north-east continued to flow to Latin America. As time progressed, remittances home and pre-paid tickets, rather than subsidized passages, helped to finance the moves of relatives and friends and non-subsidized immigration increased significantly.

The colono contracts to subsidized immigrants in the coffee plantations are the second reason why Brazil was attractive to southern European emigrants. The contracts established three separate sources of money wages. The first of these was payment for the care of coffee trees during the annual production cycle (depending on the numbers of trees per family, which in turn depended on the number of working people in the family). Wages for this work accounted for roughly one-half to two-thirds of the colono family income. The second source was payment for the coffee harvest. Labour was contracted as a family unit for the harvest; however, the income from this task fluctuated considerably from year to year because of wide variations in yields per tree, and also varied geographically, being higher in the frontier areas because of higher yield per tree. The third source of money wages was payment for occasional day labour on the plantation. ${ }^{38}$

The colono contract also included two non-monetary income sources: free housing and plantation land between coffee trees to grow one's own food and/or pasture land for livestock. Available colono family budgets suggest that the household obtained large shares of its income (in some cases over 50 per cent) from cash crops and animal products. ${ }^{39}$ Contracts also guaranteed employment after landing, thereby reducing uncertainty and search costs. Hence, the advantages that the colono contract offered to immigrants are not captured by consideration of real wages alone.

Scholars have discussed whether the labour supply from southern Europe to Latin America was more elastic than from the rest of Europe to other destinations. According to Lewis, before wages begin to rise above the subsistence level (as in Brazil after the abolition of slavery), any country could look for surplus labour in other countries. ${ }^{40}$ Leff explicitly considered nineteenth-century Brazil, and particularly São Paulo, as an example of the Lewis model ${ }^{41}$ Díaz Alejandro shared the belief that the Lewis model applied well to Argentina before the 1930s. ${ }^{42}$ More recently, Hatton and Williamson have rejected the Lewis model, pointing out that

${ }^{37}$ Sánchez-Alonso, 'Other Europeans', tab. 2. For Italy, see Federico et al., 'Origins'. See CGE, Annuario, p. 1577, for fares from Italian ports.

${ }^{38}$ Holloway, Immigrants, pp. 74-81.

${ }^{39}$ Ibid., pp. 80-5; Vangelista, Braccia.

${ }^{40}$ Lewis, 'Economic development', p. 190.

${ }^{41}$ Leff, Underdevelopment, vol. I, p. 48.

${ }^{42}$ Diaz Alejandro, Essays. Taylor, 'Mass migration', showed that Argentina's immigration was not more responsive to wage gaps than Australia's, contradicting Diaz Alejandro. 
southern European emigrants did not have a more elastic labour supply since they were no more responsive to wage gaps between home and abroad than those from other countries. ${ }^{43}$

There are three reasons why the Lewis hypothesis merits further investigation, particularly for Brazil. First, focusing on wage gaps, as Hatton and Williamson did, could be misleading, since in Brazil available data on wages present two main shortcomings. One is the small share of money wages received by coffee workers and the importance of non-monetary income sources in the colono labour contract, as explained above. The other is that Williamson's data refer to unskilled urban wages in the city of Rio de Janeiro. It is unlikely that urban wages in Rio are representative of rural wages in the coffee area. Second, the labour supply in São Paulo came not only from European immigrants (subsidized or otherwise), but increasingly from Brazilian natives and older immigrants already living in the state. The source of the elastic supply of labour, particularly for wage earners during the coffee harvest, came from within Brazil. In 1905, 45 per cent of agricultural workers in rural areas of São Paulo were Brazilian natives. Vangelista distinguishes a segmented labour market in São Paulo; European immigrants supplied the colono labour force, but colonos represented a fraction of the total labour needs on the coffee plantations. Occasional day labour for additional tasks on the plantation and workers for the harvest were increasingly provided by both native-born and foreign workers living in the city of São Paulo. ${ }^{44}$ Furtado also stressed the importance of internally recruited manpower. ${ }^{45}$ From 1903 to 1912 , 30.5 per cent of entries in the São Paulo Immigrant Hostel were immigrant workers already in the country, 26.4 per cent were non-subsidized new arrivals from Europe, and 43.1 per cent were subsidized new arrivals from Europe. Most of the re-entries were immigrants in the city who voluntarily appeared at the gates of the Hostel in search of jobs on coffee plantations. ${ }^{46}$ Likewise, Adelman suggested that the elastic labour force for the harvest in the Pampas came from immigrants already in Argentinean cities and not from the 'golondrinas' from Italy. ${ }^{47}$ The third reason to reconsider the Lewis model is the quantity of subsidized immigrants supplied to the coffee plantations by the São Paulo immigration service. If labour demand is estimated, as the number of workers needed to take care of the coffee trees in production $(2,500$ trees per worker), as done by Holloway, then the São Paulo immigration services supplied nearly five times as many workers as could have been accounted for by the expansion of coffee between 1893 and $1930 .{ }^{48}$ Holloway's is a minimum estimate since it does not include non-subsidized immigrants, internal migrant workers who did not pass through the Hostel, or the continuous entry of children into economically active age groups.

But without new data on the evolution of real wages in the rural areas of São Paulo as coffee output expanded we cannot offer conclusive evidence, although internal sources of labour appear to be more important in the total labour supply

\footnotetext{
${ }^{43}$ Hatton and Williamson, Mass migrations, ch.3.

${ }^{44}$ Vangelista, Braccia, pp. 189-91.

${ }^{45}$ Furtado, Economic growth, p. 168.

${ }^{46}$ Holloway, Immigrants, tab. 2, p. 56. The Immigrant Hostel also functioned as an employment agency for the coffee areas.

${ }^{47}$ Adelman, Frontier development, pp. 118-21.

${ }^{48}$ Holloway, Immigrants, tab. 5, p. 67.
} 
than previously thought. This may also be true during the harvest season in the Pampas in Argentina. In São Paulo, estimates of the quantity of workers needed for the continuous coffee expansion suggest that subsidies were delivering too many workers, thus reinstating the Lewis model. However, we do know that immigrants to Brazil responded to a combination of wages, transport subsidies, and the conditions of the coffee contract, rather than to wage differentials alone.

\section{III}

Immigration policies in Latin America raised few barriers to European immigration and offered rights of residence and the ability to engage in commerce comparable to those enjoyed by natives. While some countries needed to increase labour supply due to the scarcity of the native population, others tried to prevent labour shortages during harvest seasons and some governments thought that the immigration of culturally 'superior' Europeans would contribute to economic and social modernization.

Immigrants arrived in Argentina in massive numbers before and after a short period of subsidies (1887-9), while Brazil continued subsidizing European immigration until the late $1920 \mathrm{~s} .{ }^{49}$ Uruguay did not actively promote immigration, which was largely spontaneous, and Cuban immigration policy was closely calibrated to labour demand on the sugar plantations. ${ }^{50}$

Many scholars consider Argentina's immigration policy to have been open to international migration during the era of mass migration. ${ }^{51} \mathrm{~A}$ new index of its immigration policy shows that this was indeed the case, contradicting Timmer and Williamson's representation of Argentinean immigration policy as restrictive from $1890 .{ }^{52}$ Moderate restrictions increased over time, but Argentina remained open to mass migration until the 1930s. The new quantitative evidence suggests that prior to the 1930s Argentina had economic reasons to restrict immigration: decreasing relative quality of immigrants (measured by literacy), rising inequality within Argentina, and the closing of the frontier. However, restrictions remained moderate since labour needs could not be directly translated into parliamentary legislation. The unskilled labour force was overwhelmingly composed of foreigners with no voting rights. ${ }^{53}$ In fact, the leader of the Socialist Party in Argentina was in favour of massive immigration, but the Party was unable to obtain widespread support from the migrant workers, who, because of their alien status, remained outside the political system. ${ }^{54}$ Instead social unrest through strikes and labour conflicts in the 1910 s resulted in moderate restrictions in the early 1920 s (figure 6). The Argentine case highlights how inequality may affect immigration policy through labour unrest.

\footnotetext{
49 The 1890 Baring crisis ended this policy in Argentina because of financial constraints.

50 Zubillaga, 'Breve panorama'.

51 Solberg, Prairies.

52 Timmer and Williamson, 'Immigration policy'. The new index in Sánchez-Alonso, 'Making sense'. See notes to fig. 6 .

${ }^{53}$ There are two main reasons for the lack of nationalization of immigrants in Argentina: (a) keeping their nationalities so that they could seek protection from their home government when needed; and (b) the establishment of mandatory military conscription for natives after 1901 .

${ }^{54}$ Fogarty, 'Social experiments'.
} 


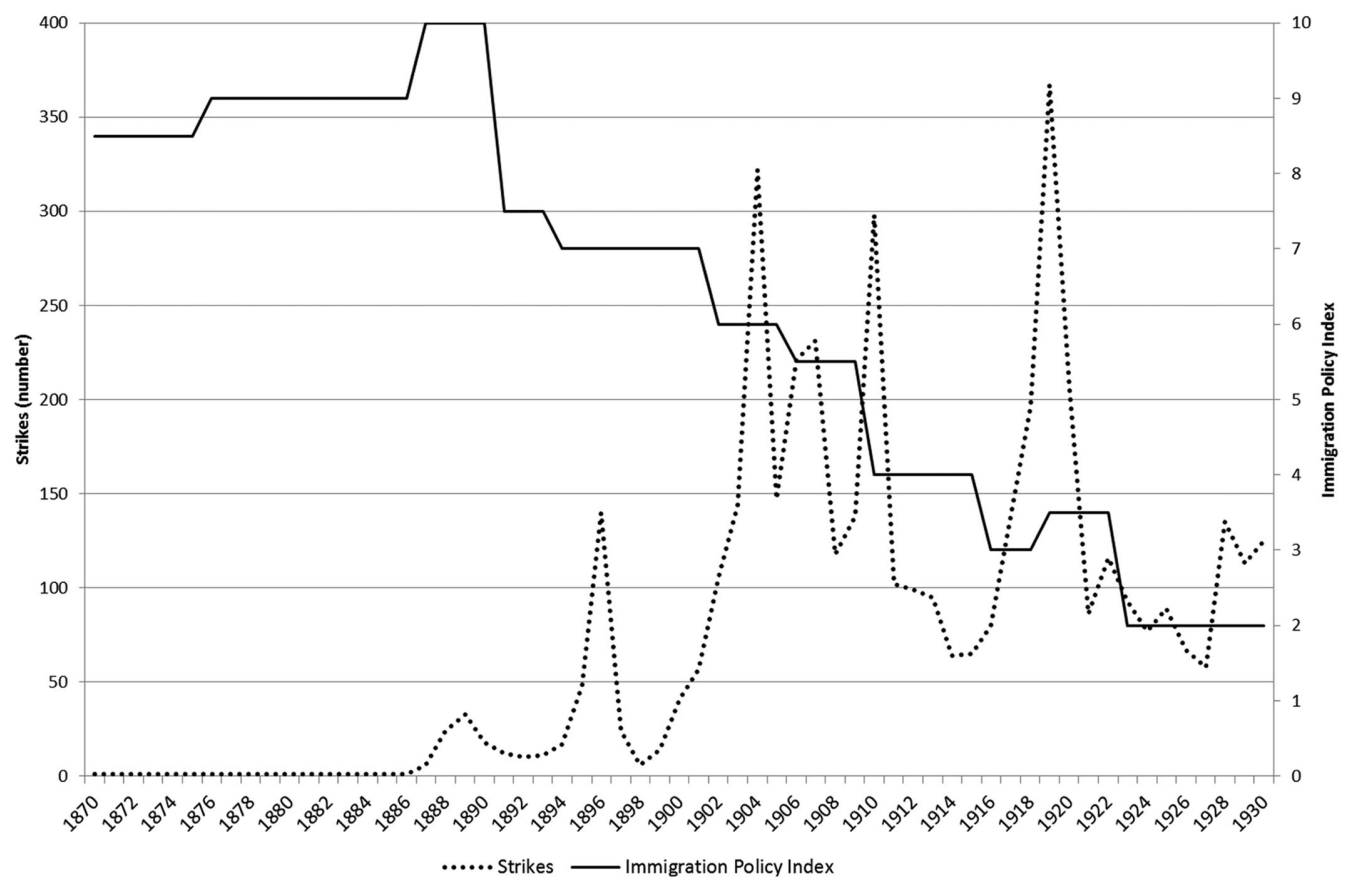

Figure 6. Immigration policy index and annual number of strikes in Argentina, 18701930

Note: The index values (right-hand scale) range from 0 to 10 , the latter being a totally open immigration policy. Sources: Index: Sánchez-Alonso, 'Making sense'. No. of strikes per year: from 1887 to 1906, Korzeniewicz, 'Labor unrest', tab. 1; from 1907 to 1930, official government statistics in Vázquez-Presedo, Estadísticas históricas, vol. II, p. 47.

An open immigration policy may suggest that Argentina was less selective than other countries. Canadian policies were less favourable to massive immigration because of a different income distribution and franchise. ${ }^{55}$ Taylor stressed that Australia's policy selected from high-wage northern European labour markets (namely Britain), while the non-selective immigration policy of Argentina drew immigrants from low-wage southern European labour markets. ${ }^{56}$

Australia had an assisted migration programme. Though the Brazilian subsidies policy was not the same as the Australian assisted scheme, both governments took an active role in attracting and selecting immigrants. ${ }^{57}$ It has been argued that in the absence of an assisted passage scheme a significant proportion of migrants to Australia would not have been able to travel. ${ }^{58} \mathrm{~A}$ similar argument can be applied to Brazil; low wages and hard working conditions on the coffee plantations would have been less attractive without subsidies. The differences between the two policies are significant, however. Contrary to what happened in Brazil, the 1890s crisis led to high levels of unemployment which made assisted immigration highly unpopular in Australia. The explicit goal of Brazilian immigration policy

\footnotetext{
55 Avery, Reluctant host; Solberg, Prairies.

56 Taylor, 'External dependence'.

${ }^{57}$ For simplicity, I refer to Brazil, though subsidized immigration only affected the state of São Paulo.

${ }^{58}$ Pope, 'Population'.
} 
was to maintain a constant labour supply, so wages were kept low. Meanwhile, in Australia, the general goal of expanding the labour supply was subject to the constraint that living standards were maintained. While in Brazil immigrants were effectively selected to work on the land, in Australia the nomination system was geared to introduce those workers 'who can readily assimilate in the industrial life'. ${ }^{59}$ Immigrants who could pay their own passage to Brazil were considered less desirable because they were presumed to enter non-agricultural occupations. ${ }^{60}$

Brazilian policy was not intended to populate the country, as in Argentina, but was specifically aimed at sustaining the production of coffee. With the cessation of slave arrivals and the final abolition of slavery, subsidizing European immigration appeared to be the best solution to maintain a constant labour supply. Funds for immigration subsidies came from tax revenues on coffee exports. After 1900 the programme changed to partial subsidies: the state paid a set fee and an annual limit on subsidized immigrants was established. The flat fee system provided less than the full price of the passage, but it still meant a considerable reduction in travel costs. ${ }^{61}$

To qualify for a subsidized passage Europeans had to meet well-defined criteria of gender, age, and family structure. At the time, no other single country had such a detailed immigration policy as Brazil. All immigrants who entered under a colono contract had to be agricultural workers and to arrive in family units. Regions of origin in southern Europe were carefully defined in their contracts. Since the shipping companies had to repatriate unsuitable immigrants, they were careful to select strictly. The system gave the authorities control over which immigrants entered and over their occupation after arrival. From 1905 to 1929, however, spontaneous immigration surpassed subsidized immigration. ${ }^{62}$ Internal migration and non-subsidized immigration increased in the 1920s and opposition to the subsidies policy grew. The policy of prepaid passages ended in 1928 and in the 1930s the programme finished.

Why did the system last so long? As the land became less fertile on the old plantations, planters moved to virgin lands on the frontier where they needed more workers. Simultaneously, older colonos, able to accumulate enough savings to buy land, established themselves as suppliers of food to the São Paulo urban market. At least one-quarter of the labour force needed to be replaced every year as thousands of colonos left the plantations to till their own plots, migrated to the cities, or abandoned Brazil. ${ }^{63}$ The colonato system could only survive with a continuous flow of workers.

Brazil had a relatively large native population. Native-born Brazilians, particularly in the north-east, might have benefited from labour demand in the south-east and internal migrants could have supplied the workforce for the plantations. It is unlikely that the transportation cost of bringing workers from one region to the other would have exceeded the cost of transporting thousands of workers from Europe to Brazil. Leff hypothesized that in the absence of subsidized

\footnotetext{
${ }^{59}$ New South Wales Parliamentary Papers (1913), quoted in Pope, 'Population', p. 48.

${ }^{60}$ Holloway, Immigrants, p. 44.

${ }^{61}$ de Carvalho Filho and Colistete, 'Education performance', tab. 1.

${ }^{62}$ In the 1910 s these non-subsidized European immigrants were more likely to go to the city of São Paulo than to the coffee areas; Vangelista, Braccia, ch. 4.

${ }^{63}$ Font, 'Coffee planters'. Many moved to Argentina or Uruguay instead of going back home.
} 
overseas immigration, most of the south-east's labour supply would have come first from the region's domestic agricultural sector and over time from the northeast. ${ }^{64}$ However, former slaves refused to work in the plantations and Merrick and Graham argued that it was not obvious that a substantial labour surplus existed in the north-east, at least in the years after abolition. Given the rapid expansion in the coffee areas, an interregional labour transfer of such magnitude would have caused serious economic and political stress between the north and the south. ${ }^{65}$ The large distances within Brazil meant transportation costs were high. Passenger railway services made labourers more geographically mobile but, given the low levels of income, for many Brazilians even the train proved too expensive. ${ }^{66}$ As in the US, the First World War provided the definitive push to internal migration. Due to the shortage of overseas immigrants, a flow of workers from other parts of Brazil to the coffee areas started during the war and grew relative to overseas inflows in the 1920s.

Faced with the abolition of slavery in the 1880s, Cuban sugar planters began to look for a large supply of wage labourers. Contrary to the position in Brazil, planters predicted a fall in wages because of competition between former slaves and workers from Europe. During colonial times, the Spanish government brought African slave labour to the sugar plantations and simultaneously tried to 'whiten' the Cuban population by attracting Spanish settlers. China provided an alternative source of labour, in the form of 125,000 Chinese indentured workers, between 1847 and $1874 .{ }^{67}$ After Independence, policy reflected a preference for permanent migration of families from Europe and the Canary Islands. Cuba attracted 780,000 Spaniards between 1900 and 1930, a figure equal to almost half the Cuban population in $1900 .{ }^{68}$ As in the rest of the continent, restrictions came in the 1930s.

Latin American immigration policy was driven by prevailing labour market conditions, although through indirect channels in Argentina. Argentina and, particularly, Brazil had non-selective immigration policies which could imply that Latin America received negatively selected immigrants. This characterization is reinforced by Latin America's attraction of immigrants from lower-wage areas of Europe. However, this representation is in need of qualification.

\section{IV}

Understanding selectivity in migration flows is important for the accurate analysis of the performance of immigrants in the host country. Migrants do not constitute a random sample of the population from their countries of origin. According to the Roy-Borjas model, prospective migrants possessing skills that are highly valuable or scarce in the destination country are the most likely to migrate. ${ }^{69}$ Positive selection takes place when the destination economy displays a higher skill premium than the home country. Negative selection takes place when the destination economy

\footnotetext{
${ }^{64}$ Leff, Underdevelopment, p. 65.

${ }^{65}$ Merrick and Graham, Population, pp. 85-90. Political fear about a possible secession was present at the time.

${ }^{66}$ Summerhill, Order, pp. 110-17.

${ }^{67}$ Scott, Slave emancipation, pp. 196-200.

${ }^{68}$ Losada, Cuba.

${ }^{69}$ Roy, 'Some thoughts'; Borjas, 'Self-selection'.
} 
Table 3. Literacy rates at home and abroad (\%)

\begin{tabular}{lcc}
\hline & Italians & Spaniards \\
\hline Argentina (1914) & 62.4 & 70.0 \\
Uruguay (1907) & 81.3 & 76.1 \\
Italy (1911) & 61.4 & 50.0 \\
Spain (1910) & & 5 \\
\hline
\end{tabular}

Sources: República Argentina, Tercer censo, vol. 3; Goebel, 'Gauchos', tab. 5; Tortella, 'Patterns'; Federico, Nuvolari, and Vasta, 'Origins'.

offers lower rewards for skill relative to the sending country. Selection could occur along a number of observable characteristics such as education, skills, or wealth and other unobservable characteristics such as youth, energy, and ambition.

Immigration to the US was positively selected from some European countries (Germany and Great Britain) and negatively selected from others (Ireland and Italy). ${ }^{70}$ It has been argued that the switch of emigrant sources from high-wage to low-wage European countries correlates with a decrease in the quality of immigrants. ${ }^{71}$ In Latin America, there was not a significant switch in emigrant sources and ethnic features were not correlated with skill levels; each community was comprised of a spectrum of occupations and skills (mostly unskilled) except for the small group of immigrants from northern Europe. Traditional interpretations have tended to extrapolate the economic backwardness of Italy, Spain, and Portugal (measured in terms of per capita GDP and relative to advanced European countries) to emigration flows. But were northern Italians migrating to Argentina in the 1880s less skilled than the Scandinavian or Irish migrants travelling to the USA in the 1860s?

Using literacy as a proxy for skills, we could ask whether those countries in Latin America that received the largest number of immigrants would have had a generally better-educated labour force had immigrants been positively selected. The question is twofold. First, were immigrants to Latin America positively selected according to literacy? Second, did immigrants to Latin America have higher levels of literacy than the native population?

Literacy rates were lower in sending southern European countries compared with northern Europe. However, comparing immigrants in Argentina and Uruguay with the total population of the country of origin in Europe shows positive selection as measured by literacy, particularly for Spaniards (table 3). In Portugal around 30 per cent of the population was literate in 1910 compared with 48 per cent of the Portuguese arriving in São Paulo. ${ }^{72}$ The proportion of Spanish immigrants arriving in Cuba who were literate ranged from 63 per cent in 1912 to 94 per cent in $1924 .^{73}$

Selection by literacy could be driven by regional origins. In the three European countries-Italy, Spain, and Portugal - the northern regions, from which most

\footnotetext{
${ }^{70}$ Abramitzky, Boustan, and Eriksson, 'Poor huddled masses'.

${ }^{71}$ Abramitzky, Boustan, and Eriksson, 'Nation of immigrants', document declining skill levels among arrival cohorts.

${ }^{72}$ Klein, 'Integration of Italian immigrants'; idem, 'Social and economic integration'.

${ }^{73}$ Losada, Cuba. There is a sharp contrast between Spaniards from the Peninsula and Canary Islanders. The latter display the lowest literacy and numeracy rates in Spain and those who left were the least skilled; Juif, 'Skill selectivity'.
} 
immigrants to Latin America were drawn, tended to be more literate than the southern regions for historical reasons. ${ }^{74}$ The selectivity of transatlantic migratory flows seems to have been lower in Italy than in other countries, since the direct cost of migration (pre-paid tickets, remittances, and so on) between Italy and the Americas was lower. The Height Gini inequality index, calculated by Stolz and Baten, shows higher inequality in Spain compared with Italy, which could explain the higher selectivity of Spanish migration. ${ }^{75}$ When immigrant literacy is compared with that of potential emigrants from regions of high emigration, positive selection appears quite clear for Spain and Portugal. ${ }^{76}$

Immigrants to Latin America had higher literacy levels than native populations. ${ }^{77}$ In 1895, 38 per cent of foreigners living in Argentina were illiterate compared to 61 per cent of natives. In Brazil and Cuba, the native populations, largely composed of black and mestizo groups, were less skilled than European workers. In Brazil, immigrants' skills and literacy levels were above those of native workers. Only 34 per cent of immigrants aged more than seven years who arrived in São Paulo between 1908 and 1936 were illiterate compared with 73 per cent of native-born people in the state in $1920 .{ }^{78}$ Spaniards and Italians living in Argentinean cities in 1895 had literacy rates that were higher than the native-born population ( 88 per cent and 78 per cent respectively).

One proxy often used to signal positive self-selection is upward mobility within and across generations. Germani was among the first scholars to point out the extraordinary upward mobility of immigrants in Argentina for both the first generation and their children. ${ }^{79}$ Moya highlights the greater opportunities for newcomers to Buenos Aires when compared with more developed and industrial cities in North America. ${ }^{80}$ When mass migration from southern Europe started, cities in the US had larger, older, and better-established networks where the workforce was numerically dominated by natives and longer-resident immigrants.

Recent empirical research shows that it was the possibility of rapid social upgrading that made Argentina attractive to immigrants. Linking data for males between the 1869 and 1895 census dates, Pérez shows that first-generation immigrants experienced faster occupational upgrading than natives. ${ }^{81}$ These results contrast with recent evidence for the US where immigrants and natives appear to have experienced similar rates of occupational upgrading. ${ }^{82}$ Using passenger lists, Pérez followed immigrants in Argentina from their arrival to the 1895 census. Occupational upgrading occurred for a large proportion of those who declared unskilled occupations on arrival. More than 75 per cent of those who entered as unskilled workers in the 1880 s had moved up to more skilled occupations

\footnotetext{
${ }^{74}$ In Spain and Portugal there was no shift in the regional origins of emigrants, as in Italy. However, even post-1880 Italian emigrants to the US were more literate than the average in southern Italy, the region from which most of them came; Bertola and Sestito, 'Comparative perspective'.

${ }^{75}$ Stolz and Baten, 'Brain drain'. Portugal is not considered in their sample.

76 Sánchez-Alonso, Causas; Rodrigues, 'Alto Minho'.

${ }^{77}$ Rocha, Ferraz and Soares, 'Human capital'.

${ }^{78}$ Klein, Inmigración española.

${ }^{79}$ Germani, 'Movilidad social'.

${ }^{80}$ Moya, Cousins and strangers. For the case of Italians, see Baily, Land of Promise; Klein, 'Integration of Italian immigrants'.

${ }^{81}$ Pérez, '(South) American dream'. Children of European immigrants displayed substantially better economic outcomes than those of the natives in literacy, occupations, and ownership.

82 Abramitzky, Boustan, and Ericksson, 'Nation of immigrants'
} 
by $1895 .{ }^{83}$ Also, in Argentina a smaller fraction of immigrants than in the US experienced occupational downgrading from skilled/semi-skilled occupations. Although Pérez fails to explain why Argentina was a good place for immigrants' social upgrading, his findings provide an economic rationale for why some Europeans chose Argentina as a destination over the US. An analysis of a sample of marriage records combining data on occupation, property ownership, and literacy supports similar conclusions for Uruguay, where immigrants were associated with the rise of a strong middle class. ${ }^{84}$

In the US, the traditional picture was one of immigrants who initially held lowerpaid occupations than natives but converged over time. Recently, Abramitzky et al. showed that the average immigrant did not face a substantial occupation-based earnings penalty upon arrival and experienced occupational advancement at the same rate as natives. Long-term immigrants from sending countries with real wages above the European median held significantly higher-paid occupations than natives upon arrival, while immigrants from sending countries with below-median wages started out in equal or lower-paid occupations. ${ }^{85}$

Argentine and Brazilian historical censuses lack information on individual earnings or income so researchers have imputed earnings to different occupations from a variety of sources. Pérez documents a very fast growth in occupational earnings among immigrants ( 6 per cent faster than among natives) between 1869 and $1895 .{ }^{86}$ For the city of Buenos Aires, Arroyo Abad and Sánchez-Alonso compare the labour market performance of Argentineans with that of the largest two immigrant groups, Italians and Spaniards, using a large new dataset for $1895 .{ }^{87}$ In this census year, leaving aside the possible selection bias in the sample because of return migration, Italian and Spanish males received, on average, 80 per cent of average native-born earnings. The weighted-average earnings for Italian and Spanish workers were very similar and, in some categories, such as crafts and services, immigrants obtained higher wages than natives (figure 7 ). ${ }^{88}$ However, clustering by occupation drives part of the differential average earning profiles between immigrants and native-born workers in the city of Buenos Aires. Empirical evidence on the role of ethnic occupational networks shows that if the concentration of established compatriots in a particular occupation and neighbourhood increased by 1 percentage point, the probability of a new immigrant following that path would increase by 8 percentage points. ${ }^{89}$

If Spanish immigrants had the advantage of the local language and higher literacy rates, why were Italians more successful in access to property and earnings? Italians had the first-mover advantage. In contrast with the US, the Italians

\footnotetext{
${ }^{83}$ Pérez, '(South) American dream', tab. 5. See also Moya, Cousins and strangers. About half of the immigrants arriving in the US in the 1840s were still working as unskilled labourers in 1860; Ferrie, 'Entry'.

${ }^{84}$ Goebel, 'Gauchos'.

${ }^{85}$ Abramitzky et al., 'Nation of immigrants'.

${ }^{86}$ Pérez, '(South) American dream'. Unfortunately, nominative records for the 1914 census were lost.

${ }^{87}$ Arroyo Abad and Sánchez-Alonso, 'City of trades'. This is a cross-section comparison for 1895. The sample of the 1895 census could be biased due to selectivity in return migration since it is possible that the Baring crisis precipitated the return of those negatively selected (see section I).

${ }^{88}$ Ibid., tab. 3. Earnings were assigned to different occupations using detailed information provided mostly by Patroni, Los trabajadores.

${ }^{89}$ Arroyo Abad and Sánchez-Alonso, 'City of trades', tab. 8. 


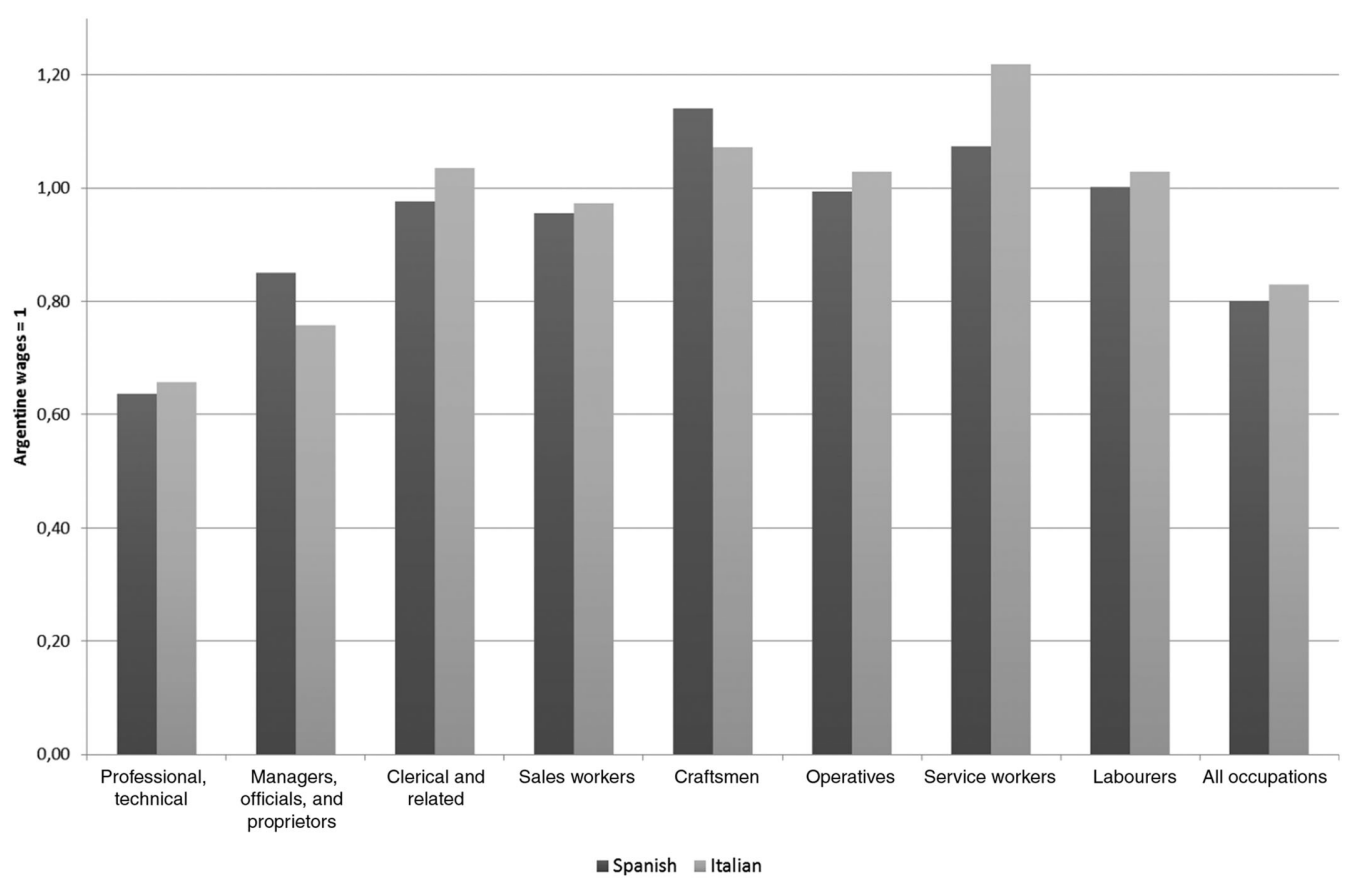

Figure 7. Relative average wages of Italian and Spanish male workers by occupational category (Argentines = 1), Buenos Aires, 1895

Source: See Arroyo Abad and Sánchez-Alonso, 'City of trades', app., for the imputation of wages to each category.

in Argentina were the first mass-immigration arrivals. ${ }^{90}$ Early arrival and not having to compete with older, established immigrants mattered. The higher levels of affluence and prosperity of Italians in Buenos Aires were not based on superior earnings or skills but on older and denser networks. In contrast, Spanish immigrants had two important disadvantages: later arrival and a demographic structure that exhibited an increasing family size over time, and thus higher rates of dependency. Consequently, a lower savings capacity proved to be an obstacle for higher social mobility in the Spanish case. ${ }^{91}$ Emigration of Spanish families to Argentina shows a reverse trend when compared with Italians. In 1895, more than half of Italians arrived in family groups, while this was the case for only 17 per cent of the Spanish (table 4). The average size of Spanish families was 2.3 compared with 3.4 members in the average Italian family. In 1913 the situation reversed; more than 40 per cent of Spaniards arrived in family groups, a higher proportion than among the Italians or than the total immigrant population. It seems that the advantages that the Spaniards had in Argentina, thanks to a common language, higher literacy rate, and cultural affinity, were counterbalanced by the

\footnotetext{
${ }^{90}$ For the traditional view, see Devoto, Historia de los italianos. In the 1880 s the proportion of Italian arrivals in Argentina compared with Spaniards was 14 to 1.

${ }_{91}$ Taylor, 'External dependence', stressed the high dependency ratio of immigrants in Argentina compared with Australia.
} 
Table 4. Family immigration to Argentina, 1895 and 1913

\begin{tabular}{lcccc}
\hline & $\begin{array}{c}\text { Immigrants with } \\
\text { family }\end{array}$ & $\begin{array}{c}\text { Average size of the } \\
\text { family }\end{array}$ & $\begin{array}{c}\text { Immigrants without } \\
\text { family }\end{array}$ & $N$ \\
\hline 1895 & $\%$ & & $\%$ & \\
Spanish & 16.8 & 2.3 & 83.0 & 11,288 \\
Italian & 56.7 & 3.4 & 53.2 & 41,203 \\
All immigrants & 48.0 & 3.2 & & 61,226 \\
1913 & & 3.2 & 56.7 & 122,271 \\
Spanish & 43.2 & 2.8 & 57.4 & 114,252 \\
Italian & 42.6 & 3.0 & 58.5 & 302,047 \\
All immigrants & 41.5 & & & \\
\hline
\end{tabular}

Source: Sánchez-Alonso, 'Inmigración española', p. 209.

immigration of family units and, consequently, a higher dependency rate than the Italians.

Access to property in the host country represented upward mobility for many Europeans. Immigrants were successful in moving rapidly to a prominent position in Brazil's socio-economic structure. Colonos had access to land where they could produce for their own subsistence and eventually for the market. This source of cash income enabled savings and social mobility. ${ }^{92}$ Italian owners of rural property represented 14.3 per cent of households in the richest areas of São Paulo, whereas the Portuguese comprised just 3.6 per cent of property owners in this area. ${ }^{93}$ In Brazil, Spaniards did reasonably well in access to property in agriculture, despite their disadvantages in relation to education. They did not do so well in business, commerce, and industry compared with Italians and the Portuguese. Spaniards enjoyed a privileged position in Cuba even after Independence; their probability of joining the ranks of white-collar workers was higher than in any other country. ${ }^{94}$

In Argentina, Italian-born immigrants did extremely well in landownership. According to the 1914 population census, 25 per cent of Italians aged 20 and over owned some type of property, a figure only slightly below native-born Argentines. In contrast, only 16 per cent of Spanish immigrants owned property. ${ }^{95}$ Many Portuguese in Brazilian cities became school teachers, clerks, and other semi-skilled professionals but, again, the literature finds the Italians to be the most successful group in access to property. ${ }^{96}$ The high rate of ownership for Italians, considered the archetype of temporary migrants, is striking.

European immigrants overall were successful in their adjustment to Latin American labour markets. As immigrants were often positively selected from their countries of origin according to literacy, it seems that selection played a role in explaining their success in host labour markets. However, more definite conclusions require new data.

\footnotetext{
${ }^{92}$ Font, 'Coffee planters'; idem, Coffee and transformation. See Vidal Luna, Klein, and Summerhill, 'Characteristics', for the emergence of an agrarian economy of small and medium-sized producers in São Paulo.

${ }^{93}$ Holloway, Immigrants, tab. 7, p. 149.

${ }^{94}$ Klein, Inmigración española.

${ }^{95}$ República Argentina, Tercer censo.

${ }^{96}$ Holloway, Immigrants.
} 
In recent years, a large body of literature has proposed alternative explanations for the different levels of development between world regions. Literature linking longrun determinants of economic growth in the Americas to political and economic institutions in the colonial period is abundant; however, Glaeser et al. argue that the human capital brought by immigrants is a more convincing explanation for economic growth and institutional development. ${ }^{97}$ European immigrants carried something with them-human capital and culture-that explains current differences in economic development. Linking immigrants' human capital to longrun economic and educational outcomes has been the focus of recent research for Brazil and Argentina.

The prevalent view is that Brazil attracted the poorest of the poor and the least well-educated immigrants from Europe because of its policy of subsidizing immigration. However, immigrants still brought human capital with them and had a positive effect on the supply of schools. Immigrants with higher literacy levels than natives, and possibly with some previous experience in manufacturing, not only demanded more schooling but were also able to take advantage of the industrialization process that started in São Paulo in the 1920s. De Carvalho Filho and Colistete find a positive and enduring effect of the presence of foreignborn immigrants on the supply of public instruction in São Paulo. ${ }^{98}$ In Argentina, however, empirical results differ; areas with higher shares of European immigrants are associated with a higher number of private schools and a lower number of public schools, pointing more to the individual decisions of citizens than to educational policies increasing the supply of schooling because of immigrants' demands. ${ }^{99}$ In the US, immigration of adults with lower skills than natives made education more attractive to natives by altering the relative supply of skills in the economy. This does not seem to have been the case in Latin American countries since immigrants were more educated than the native population. ${ }^{100}$

Scholars argued that early European immigrants to official colonies in São Paulo were positively self-selected according to skills, in contrast with the mass of relatively low-skilled immigrants arriving later in the coffee frontier. Germans, Italians, and Swiss were the main groups in the colonies. Immigrant farm labourers in São Paulo established their own community schools while simultaneously pressing for public funding for public schools. The effects of the early adoption of public instruction can be detected more than 100 years later in the form of better test scores and higher income per capita in the regions of São Paulo where immigrants settled. ${ }^{101}$ Similar results are found in studies of the long-term consequences of the government-sponsored programmes of European immigration to southern Brazil before the Great War. ${ }^{102}$ State-sponsored settlements in São

\footnotetext{
${ }^{97}$ In the first group, among others, are Engerman and Sokoloff, 'Factor endowments'; Easterly and Levine, 'European origins'; Acemoglu, Johnson, and Robinson, 'Colonial origins'; eisdem, 'Reversal of fortunes'. See Glaeser, La Porta, Lopez-de-Silanes, and Shleifer, 'Institutions', for the emphasis on human capital.

${ }_{98}$ de Carvalho Filho and Colistete, 'Education performance'.

${ }^{99}$ See Droller, 'Migration', for Argentina.

100 Lafortune, Tessada, and Gazmuri, 'Lured in or crowded out?'

${ }^{101}$ Data refer to the municipalities in the state of São Paulo in 1907; de Carvalho Filho and Colistete, 'Education performance'.

${ }^{102}$ See de Carvalho Filho and Monasterio, 'Immigration', for settlements in Rio Grande do Sul. 
Paulo were created for food production for the growing urban area but, contrary to the policy of subsidized mass migration, settlements were meant to attract highquality immigrants through the prospect of land ownership in inhabited regions. Today municipalities closer to the original settlements have higher per capita income, less poverty, and better health and education outcomes. Average income per capita in 2000 was 15 per cent higher in those municipalities that had a statesponsored colony early in the twentieth century. Long-run effects worked through a greater supply of educational inputs and shifts in the structure of occupations toward skill-intensive sectors. ${ }^{103}$

German colonies are the obvious candidate when looking for a positive shock in human capital and the persistence of its effects over time. Germans not only had higher literacy rates than natives, but also than southern European immigrants. Areas close to German colonies in the state of Rio Grande do Sul show less inequality and high educational levels today. In São Paulo, the presence of German-speaking immigrants per se did not create a persistent impact on the later accumulation of human capital in the state ${ }^{104}$ Moreover, there is a negative effect on enrolment in 1872, explained by the opportunity cost of schooling for those immigrants working on the land. German ethnic schools had a strong positive impact on enrolment in both private and state schools in the short run (1910), but the effect of ethnic schools persisted only through spillovers and contagion to state schools. Others have argued that the major explanation for educational performance in Brazil is export tax revenues that have financed education at the state level, rather than any impact of immigrants. ${ }^{105}$

Stolz et al. assess the impact of European immigrants for the whole country. ${ }^{106}$ With a new sample of nineteenth-century mass migrants for which they can observe human capital endowments (in this case numeracy), they show that international migration had a positive effect on the stock of human capital in Brazil. Increases in numeracy are positively correlated with immigration, even after controlling for educational expenditures at state level. They conclude that human capital grew more in those states where most immigrants arrived and the long-run effect on real GDP per capita in the year 2000 is significant.

As for Brazil, recent research in Argentina has also focused on the longrun consequences of European immigration. Droller shows that counties with historically higher shares of European immigrants had higher per capita GDP and a greater proportion of skilled workers in 2001. ${ }^{107}$ This long-run effect is linked to the higher level of human capital of immigrants and to the fact that Europeans also provided skilled labour for industry. There were also short-run effects which were not considered by Droller since mass immigration pushed the Argentinean government to invest in education. In 1884 primary education became compulsory and free. The growing number of foreign schools gave the definitive push to using state primary education to transmit national values to immigrants' children. Literacy rates increased in Argentina from 36.8 per cent in the 1880 s to 71.3 per cent in the 1920 s.

\footnotetext{
${ }^{103}$ Rocha, Ferraz, and Soares, 'Human capital'.

104 de Carvalho Filho and Monasterio, 'Immigration'. For São Paulo, see Witzel de Souza, 'Immigration'.

${ }^{105}$ Musacchio, Martinez-Fritscher, and Viarengo, 'Colonial institutions'.

106 Stolz, Baten, and Botelho, 'Growth effects'.

${ }^{107}$ Droller, 'Migration'.
} 
Finally, we can consider whether immigrants add special skills or entrepreneurial capacities to the local labour force. Ferrie and Mokyr infer positive selection from the over-representation of immigrants among US entrepreneurs. ${ }^{108}$ European immigrants in Latin America seem to have been over-represented among proprietors of industrial and commercial firms. Germani stressed the exceptional contribution of immigrants and their children to the development of an entrepreneurial class in Argentina. ${ }^{109}$ Immigrants accounted for disproportionately large shares of the workers in São Paulo and Buenos Aires manufacturing industries. Droller estimated that an increase of one percentage point in the share of highly skilled Europeans in the Pampa counties in 1914 raised the number of industrial establishments by 130 per cent by the 1930s. The same increase in the proportion of low-skilled Italian and Spanish migrants raised the number of industrial establishments by 5 per cent. ${ }^{110}$

Dean argues that immigrants and their children played an important role as entrepreneurs in the industrialization of São Paulo and Cardoso stresses that immigrant labour was crucial in promoting industry in the city. ${ }^{111}$ Pereira's inquiry into the ethnic origins of the founders of industrial establishments in São Paulo reveals that first- and second-generation Italians constituted the largest single ethnic group, even in comparison to those whose grandfathers were natives. ${ }^{112}$ Conversely, Leff argues that immigration was not a sufficient condition to promote development in Brazil. Without important economic changes, such as the emergence of an internal labour market and the expansion of railways, industrial development would never have kicked off. He argues that, if overseas immigrants had not been available, the supply of labour for the growing demand of industrial workers in São Paulo could have come from domestic sources. ${ }^{113}$

We could ask whether, without a large supply of European immigrants available to work on the coffee plantations, Brazilian natives would have been better off. Leff argues that São Paulo planters would have been forced to offer considerably higher wages to native workers, potentially leading to a better income distribution, laboursaving innovations in agriculture, and a more dynamic local market. ${ }^{114}$ Others argue that such a scenario would have reduced the comparative advantage of Brazil over other coffee producers and would have eliminated the positive externalities of exports. Given the existence of a frontier, European immigrants 'created' new jobs without displacing native workers. ${ }^{115}$ Quantitative evidence shows a surprisingly high share of native workers in the rural labour force in early twentieth-century São Paulo. Native Brazilians represented 45 per cent of rural workers and were present on two-thirds of coffee estates. ${ }^{116}$ If Europeans displaced native-born workers they did so in lower proportions than previously believed.

New research presents evidence of path dependency linking past immigrants' human capital and present outcomes in economic development without fully

\footnotetext{
108 Ferrie and Mokyr, 'Immigration'.

${ }^{109}$ Germani, Estructura.

${ }^{110}$ Droller, 'Migration', tab. 9. High-skilled immigrants were the British, French, and Germans.

${ }^{111}$ Dean, Industrialization; Cardoso, Mudanças; Merrick and Graham, Population.

112 Pereira, Empresários, pp. 70-5.

${ }^{113}$ Leff, 'Economic development', pp. 58-60.

${ }^{114}$ Leff, 'Tropical trade'.

${ }^{115}$ Merrick and Graham, Population.

${ }^{116}$ Vidal Luna et al., 'Characteristics'.
} 
explaining the mechanisms for persistence. The impact of immigration in those areas with higher shares of Europeans appears to be important since immigrants demanded and created schools (public or private). Recent research has focused on Brazilian colonies; additional research on Argentina, where literacy levels for different immigrant groups were similar, would improve our understanding of the impact of immigration in the long run. European immigrants and their children also had positive impacts on economic growth in Latin America in the short and long run, both as entrepreneurs and as an industrial labour force.

\section{VI}

Much has been written on the international mass migration of Europeans and some efforts have been made to rebalance the existing Anglo-Saxon bias in migration history. This survey has focused on immigrants to Latin America: whether they were positively or negatively selected, their social and economic assimilation to destination labour markets, and the impact of immigration policies. Poor and scarce data have been traditionally blamed as the major obstacles facing research in Latin America; however, recent literature shows that researchers are either identifying new quantitative evidence or exploiting existing data in new ways. The most revealing aspect of this research is that it shows the positive long-run effects of European immigrants in Latin America, particularly through human capital accumulation. Relatedly, recent research shows that it was the possibility of rapid occupational upgrading that made Latin America attractive to immigrants.

Immigrants came from the economically backward areas of southern and eastern Europe. Yet migrants to Latin America from southern European countries were positively selected from their countries of origin judged by literacy levels. More research is needed on other migration flows, such as eastern Europeans or the Japanese in Brazil, to identify if this occurred more generally. Literacy rates, and probably skills, were higher among immigrants compared with the population of origin and, despite non-selective immigration policies, Latin American countries received immigrants with higher levels of human capital than their native populations. The adjustment of immigrants to host labour markets also seems to have been successful, particularly in achieving access to property and in the large share of owners in industry and commerce. The success of Italians in Argentina, in relation to Spaniards, suggests that other factors may also have played a role: an early arrival, the large size of the existing community, their ability to create efficient occupational and social networks, and possibly a favourable demographic profile in the immigration flow. However, almost all European communities experienced a strong and fast upward social mobility in the destination countries. Whether this was because of positive selection at home or because of the relatively low skill levels in the host societies is still an open question.

We cannot be conclusive about the positive or negative selection of returned migrants. For Italians a consensus exists that return migration was a planned lifetime strategy for improving living standards at home, and if so, Italian returnees cannot be considered to have failed-rather the opposite. Unfortunately, nothing definitive can be said about those returning to Portugal or Spain. 
Transport subsidies and the peculiarities of the colono contract in the coffee areas seem more important explanations than real wage differentials for understanding how Brazil competed for workers in the international labour market. The Brazilian experience deserves new research in three areas: the impact of subsidies in removing poverty constraints that might have inhibited migration from southern Europe, a new institutional economics approach to colono contracts, and real wages for São Paulo rural areas that would clarify the elasticity of the labour supply from southern Europe. Discussing the Lewis model with the available evidence has focused on two factors. First, labour supply increased faster than the number of workers needed for the coffee expansion because of subsidies and, second, labour markets in São Paulo were segmented and European immigrants supplied only a fraction (though a substantial one) of the total labour force needed for the coffee plantations. The internal supply of workers became increasingly important and must be included in the total labour supply. Finally, the political economy of immigration policy of Argentina shows a more complicated story than the classic representation of landowners constantly supporting an open-door policy; this calls for new research elsewhere, particularly on Brazil and Cuba. Recent research is providing answers and posing questions that show that Latin America has much to add to debates on the economic and social impact of historical immigration.

DOI: $10.1111 /$ ehr. 12787

\section{Footnote references}

Abramitzky, R., Boustan, L. P., and Eriksson, K., 'Europe's tired, poor, huddled masses: self-selection and economic outcomes in the age of mass migration', American Economic Review, 102 (2012), pp. 1832-56.

Abramitzky, R., Boustan, L. P., and Eriksson, K., 'A nation of immigrants: assimilation and economic outcomes in the age of mass migration', Fournal of Political Economy, 122 (2014), pp. 467-506

Acemoglu, D., Johnson, S., and Robinson, J. A., 'The colonial origins of comparative development: an empirical investigation', American Economic Review, 91 (2001), pp. 1369-401.

Acemoglu, D., Johnson, S., and Robinson, J. A., 'Reversal of fortune: geography and institutions in the making of the modern world income distribution', Quarterly fournal of Economics, 117 (2002), pp. 1231-94.

Adelman, J., Frontier development. Land, labour and capital on the wheatlands of Argentina and Canada, 1890-1914 (Oxford, 1994).

Arroyo Abad, L. and Sánchez-Alonso, B. 'A city of trades: Spanish and Italian immigrants in late-nineteenthcentury Buenos Aires, Argentina', Cliometrica, 12 (2018), pp. 343-76.

Astorga, P., 'Real wages and skill premiums in Latin America, 1900-2011', Revista de Historia Económica/fournal of Iberian and Latin American Economic History, 35 (2017), pp. 319-53.

Astorga, P. and Fitzgerald, V., 'The standard of living in Latin America during the twentieth century', Development Studies Working Paper 117 (1998).

Avery, D., Reluctant host: Canada's response to immigrant workers, 1896-1994 (Toronto, 1995).

Baganha, M. I. B., 'Portuguese transatlantic migration', in S. L. Baily and E. J. Miguez, eds., Mass migration to modern Latin America (Wilmington, Del., 2003), pp. 51-68.

Baily, S. L., Immigrants in the Land of Promise: Italians in Buenos Aires and in New York City, 1870 to 1914 (New York, 1999).

Balderas, J. U. and Greenwood, M. J., 'From Europe to the Americas: a comparative panel-data analysis of migration to Argentina, Brazil, and the United States, 1870-1910', Fournal of Population Economics, 23 (2010), pp. $1301-18$.

Bandiera, O., Rasul, I., and Viarengo, M., 'The making of modern America: migratory flows in the age of mass migration', Fournal of Development Economics, 102 (2013), pp. 23-47.

Bertola, G. and Sestito, P., 'A comparative perspective on Italy's human capital accumulation', Quaderni di Storia Economica, 6 (2011).

Bértola, L. and Ocampo, J. A., The economic development of Latin America since independence (Oxford, 2012).

Borjas, G. J., 'Self-selection and the earnings of immigrants', American Economic Review, 77 (1987), pp. $531-53$.

Bulmer-Thomas, V., The economic history of Latin America since independence (2nd edn., Cambridge, 2003).

Bulmer-Thomas, V., The economic history of the Caribbean since the Napoleonic Wars (Cambridge, 2012).

Cardoso, F. H., Mudanças sociais na América Latina (São Paulo, 1969). 
de Carvalho Filho, I. and Colistete, R. P., 'Education performance: was it all determined 100 years ago? Evidence from São Paulo, Brazil', Munich Personal RePEc Archive paper, no. 24494 (2010), https://mpra.ub.uni-muenchen.de/24492/ (accessed on 30 March 2018).

de Carvalho Filho, I. and Monasterio, L., 'Immigration and the origins of regional inequality: governmentsponsored European migration to southern Brazil before World War I', Regional Science and Urban Economics, 42 (2012), pp. 794-807.

Chiswick, B. R. and Hatton, T. J., 'International migration and the integration of labor markets', in M. D. Bordo, A. M. Taylor, and J. G. Williamson, eds., Globalization in historical perspective (Chicago, Ill., 2003), pp. 65-119.

Cinel, D., From Italy to San Francisco. The immigrant experience (Stanford, Calif., 1982).

Dean, W., The industrialization of São Paulo, 1880-1945 (Austin, Tex., 1969).

Devoto, F. J., Historia de los italianos en la Argentina (Buenos Aires, 2006).

Diaz Alejandro, C., Essays on the economic history of the Argentine Republic (New Haven, Conn., 1970).

Droller, F., 'Migration, population composition and long run economic development: evidence from settlements in the Pampas', Economic fournal (2017), DOI: 10.1111/ecoj.12505.

Dustmann, C., 'Return migration, wage differentials, and the optimal migration duration', IZA (Institute of Labor Economics) discussion paper ser., no. 264 (2001).

Easterly, W. and Levine, R., 'The European origins of economic development', fournal of Economic Growth, 21 (2016), pp. 225-57.

Eltis, D., 'Free and coerced transatlantic migrations: some comparisons', American Historical Review, 88 (1983), pp. 251-80.

Emmer, P. C., 'Immigration into the Caribbean: the introduction of Chinese and East Indian indentured laborers between 1839 and 1917', in P. C. Emmer and M. Mörner, eds., European expansion and migration. Essays on the intercontinental migration from Africa, Asia and Europe (New York, 1992), pp. 245-76.

Engerman, S. L. and Sokoloff, K. L., 'Factor endowments, institutions, and differential paths of growth among New World economies: a view from economic historians of the United States', in S. Harber, ed., How Latin America fell behind. Essays on the economic histories of Brazil and Mexico, 1800-1914 (Stanford, Calif., 1997), pp. 260-304.

Faini, R. and Venturini, A., 'Italian emigration in the pre-war period', in T. J. Hatton and J. G. Williamson, eds., Migration and the international labor market, 1850-1939 (1994), pp. 72-90.

Federico, G., Nuvolari, A., and Vasta, M., 'The origins of the Italian regional divide: Evidence from Real Wages, 1861-1913', Fournal of Economic History (forthcoming).

Ferenczi, I. and Willcox, W. F., International migrations, vols. 1 and 2 (New York, 1929, 1931).

Ferreira Levy, M. S., 'O papel da migracao internacional na evolucao da populacao brasileira (1872-1972)', Revista de Saúde Pública, 8, suppl. (1974), pp. 49-90.

Ferrie, J. P., 'The entry into the US labor market of antebellum European immigrants, 1840-1860', Explorations in Economic History, 34 (1997), pp. 295-330.

Ferrie, J. P. and Mokyr, J., 'Immigration and entrepreneurship in the nineteenth century US', in H. Giersch, ed., Economic aspects of international migration (Berlin, 1994), pp. 115-38.

Fogarty, J., 'Social experiments in regions of recent settlement: Australia, Argentina and Canada', in D. C. M. Platt, ed., Social welfare 1850-1950. Australia, Argentina and Canada compared (1989), pp. 179-99.

Font, M. A., 'Coffee planters, politics and development in Brazil', Latin American Research Review, 22, 3 (1987), pp. 69-90.

Font, M. A., Coffee and transformation in São Paulo, Brazil (Lanham, Md., 2010).

Franzina, E., Merica! Merica! Emigrazione e colonizazzione nelle lettere dei contadini veneti in America Latina, 1876 1902 (Milan, 1979).

Fretz, J. W., Immigrant group settlement in Paraguay: a study in the sociology of colonization (North Newton, Kans., 1962).

Furtado, C., The economic growth of Brazil. A survey from colonial to modern times, R. W. de Aguiar and E. C. Drysdale, trans. (Berkeley, Calif., 1968).

Germani, G., Estructura social de la Argentina: análisis estadístico (Buenos Aires, 1955).

Germani, G., 'Movilidad social en la Argentina. Apéndice', in S. M. Lipset and R. Bendix, eds., Movilidad social en la sociedad industrial (Buenos Aires, 1963), pp. 317-66.

Glaeser, E. L., La Porta, R., Lopez-de-Silanes, F., and Shleifer, A., 'Do institutions cause growth?', fournal of Economic Growth, 9 (2004), pp. 271-303.

Goebel, M., 'Gauchos, Gringos and Gallegos: the assimilation of Italian and Spanish immigrants in the making of modern Uruguay, 1880-1930', Past and Present, 208 (2010), pp. 191-229.

Gomellini, M. and Ó Gráda, C., 'Outward and inward migrations in Italy: a historical perspective', Quaderni di Storia Economica, 11 (2011).

Hatton, T. J., 'The cliometrics of international migration: a survey', fournal of Economic Surveys, 24 (2010), pp. 941-69.

Hatton, T. J. and Williamson, J. G., The age of mass migration. Causes and economic impact (New York, 1998). 
Hatton, T. J. and Williamson, J. G., Global migration and the world economy. Two centuries of policy and performance (Cambridge, Mass., 2005).

Holloway, T. H., Immigrants on the land. Coffee and society in São Paulo, 1886-1934 (Chapel Hill, NC, 1980).

Juif, D., 'Skill selectivity in transatlantic migration: the case of Canary islanders in Cuba', Revista de Historia Económica/Fournal of Iberian and Latin American Economic History, 33 (2015), pp. 189-222.

Klein, H. S., 'The integration of Italian immigrants into the United States and Argentina: a comparative analysis', American Historical Review, 88 (1983), pp. 306-29.

Klein, H. S., 'The social and economic integration of Portuguese immigrants in Brazil in the late nineteenth and twentieth centuries', Fournal of Latin American Studies, 23 (1991), pp. 309-37.

Klein, H. S., La inmigración española en Brasil: siglos XIX y XX (Gijón, 1996).

Klein, H. S., The Atlantic slave trade (Cambridge, 1999).

Korzeniewicz, R. P., 'Labor unrest in Argentina, 1887-1907', Latin American Research Review, 24, 3 (1989), pp. 71-98.

Lafortune, J., Tessada, J., and Gazmuri, A., 'Lured in or crowded out? Estimating the impact of immigration on natives' education using early XXth century US immigration', Pontifical Catholic Univ. of Chile, working paper (2014).

Leff, N. H., 'Tropical trade and development in the nineteenth century: the Brazilian experience', fournal of Political Economy, 81 (1973), pp. 678-96.

Leff, N. H., Underdevelopment and development in Brazil. Economic structure and change, 1822-1947, vol. I (1982).

Leff, N. H., 'Economic development in Brazil, 1822-1913', in S. Haber, ed., How Latin America fell behind. Essays on the economic histories of Brazil and Mexico, 1800-1914 (Stanford, Calif., 1997), pp. 34-64.

Lewis, W. A., 'Economic development with unlimited supplies of labour', Manchester School, 22 (1954), pp. 139-91.

Losada, A. F., Cuba: población y economía entre la independencia y la revolución (Vigo, 1999).

McKeown, A., 'Global migration, 1846-1940', Fournal of World History, 15 (2004), pp. 155-89.

Maluquer de Motes, J., Nación e inmigración: los españoles en Cuba (ss. XIX y XX) (Gijón, 1992).

Martínez Shaw, C., La emigración española a América (1492-1824) (Colombres, 1994).

Masterson, D. M. (with Funada-Classen, S.), The fapanese in Latin America (Urbana, Ill., 2004).

Merrick, T. W. and Graham, D. H., Population and economic development in Brazil, 1800 to the present (Baltimore, Md., 1979).

Moya, J. C., Cousins and strangers. Spanish immigrants in Buenos Aires, 1850-1930 (Berkeley, Calif., 1998).

Musacchio, A., Martinez-Fritscher, A., and Viarengo, M., 'Colonial institutions, trade shocks, and the diffusion of elementary education in Brazil, 1889-1930', fournal of Economic History, 74 (2014), pp. 730-66.

Nahum, B., ed., Estadísticas históricas del Uruguay, vol. I (Montevideo, 2007).

Patroni, A., Los trabajadores en la Argentina (Buenos Aires, 1897).

Pereira, L. C. B., Empresários e administradores no Brasil (São Paulo, 1974).

Pérez, S., 'The (South) American dream: mobility and economic outcomes of first- and second-generation immigrants in nineteenth-century Argentina', fournal of Economic History, 77 (2017), pp. 971-1006.

Pope, D. H., 'The push-pull model of Australian migration', Australian Economic History Review, 16 (1976), pp. 144-52.

Pope, D. H., 'Population and Australian economic development, 1900-1930', in R. Maddock and I. W. McLean, eds., The Australian economy in the long run (Cambridge, 1987), pp. 33-60.

Rocha, R., Ferraz, C., and Soares, R. R., 'Human capital persistence and development', American Economic fournal: Applied Economics, 9, 4 (2017), pp. 105-36.

Rodrigues, H. F., 'Alto Minho no século XIX. Contextos migratórios sócio-culturais e familiares' (unpub. Ph.D. thesis, Univ. of Porto, 2003).

Roy, A. D., 'Some thoughts on the distribution of earnings', Oxford Economic Papers, 3 (1951), pp. $135-46$.

Sánchez-Albornoz, N., The population of Latin America: a history (Berkeley, Calif., 1974).

Sánchez-Alonso, B., Las causas de la emigración española, 1880-1930 (Madrid, 1995).

Sánchez-Alonso, B., 'Those who left and those who stayed behind: explaining emigration from the regions of Spain, 1880-1914', fournal of Economic History, 60 (2000), pp. 730-55.

Sánchez-Alonso, B., 'La inmigración española en Argentina, 1880-1914: capital humano y familia', in C. E. Lida and J. A. Piqueras, eds., Impulsos e inercias del cambio económico. Ensayos en honor a Nicolás Sánchez-Albornoz (Valencia, 2004), pp. 197-230.

Sánchez-Alonso, B., 'The other Europeans: immigration into Latin America and the international labour market (1870-1930)', Revista de Historia Económica/fournal of Iberian and Latin American Economic History, 25 (2007), pp. 395-426.

Sánchez-Alonso, B., 'Making sense of immigration policy: Argentina, 1870-1930', Economic History Review, 66 (2013), pp. 601-27.

Scott, R. J., Slave emancipation in Cuba. The transition to free labor, 1860-1899 (Princeton, NJ, 1985).

Solberg, C. E., The prairies and the pampas: agrarian policy in Canada and Argentina, 1880-1930 (Stanford, Calif., 1987). 
Stolz, Y. and Baten J., 'Brain drain in the age of mass migration: does relative inequality explain migrant selectivity?', Explorations in Economic History, 49 (2012), pp. 205-20.

Stolz, Y., Baten, J., and Botelho, T., 'Growth effects of nineteenth-century mass migrations: "Fome Zero" for Brazil?', European Review of Economic History, 17 (2013), pp. 95-121.

Summerhill, W. R., Order against progress. Government, foreign investment, and railroads in Brazil, 1852-1913 (Stanford, Calif., 2003).

Taylor, A. M., 'External dependence, demographic burdens and Argentine economic development after the Belle Époque', fournal of Economic History, 52 (1992), pp. 907-36.

Taylor, A. M., 'Mass migration to distant southern shores. Argentina and Australia, 1870-1939', in T. J. Hatton and J. G. Williamson, eds., Migration and the international labor market, 1850-1939 (1994), pp. 91-115.

Timmer, A. S. and Williamson, J. G., 'Immigration policy prior to the 1930s: labor markets, policy interactions, and globalization backlash', Population and Development Review, 24 (1998), pp. 739-71.

Todaro, M. P., 'A model of labor migration and urban unemployment in less developed countries', American Economic Review, 59 (1969), pp. 138-48.

Tortella, G., 'Patterns of economic retardation and recovery in south-western Europe in the nineteenth and twentieth century', Economic History Review, XLVII (1994), pp. 1-21.

Vangelista, C., Le braccia per la fazenda. Immigrati e 'caipiras' nella formazione del mercato del lavoro paulista (18501930) (Milan, 1982).

Vázquez-Presedo, V., Estadisticas históricas argentinas (comparadas), 2 vols. (Buenos Aires, 1976).

Vidal Luna, F., Klein, H. S., and Summerhill, W. S., 'The characteristics of coffee production and agriculture in the state of São Paulo in 1905', Agricultural History, 90 (2016), pp. 22-50.

Williamson, J. G., 'The evolution of global labor markets since 1830: background evidence and hypotheses', Explorations in Economic History, 32 (1995), pp. 141-96.

Williamson, J. G., 'Real wages and relative factor prices in the third world 1820-1920: Latin America', Dept. of Economics, Harvard Univ., Harvard Institute of Economic Research discussion paper, no. 1853 (1998).

Williamson, J. G., 'Real wages inequality and globalization in Latin America before 1940', in P. Martín Aceña, A. Meisel, and C. Newland, eds., La historia económica en América Latina, Revista de Historia Económica, special issue (1999), pp. 101-42.

Witzel de Souza, B. G., 'Immigration and the path dependence of education: the case of German-speakers in São Paulo, Brazil (1840-1920)', Economic History Review, 71 (2018), pp. 506-39.

Yañez, C., La emigración española a América (siglos XIX y XX) (Colombres, 1994).

Zubillaga, C., 'Breve panorama de imigraçao maciça no Uruguai (1970-1931)', in B. Fausto, ed., Fazer a América (São Paulo, 1999), pp. 461-504.

\section{Official publications}

CGE (Commissariato Generale dell'Emigrazione), Annuario statistico della emigrazione italiana dal 1876 al 1925 (Rome, 1926).

Dirección General de Inmigración, Resumen estadístico del movimiento migratorio en la República Argentina, 18571924 (Buenos Aires, 1925).

Instituto Panamericano de Geografía e Historia, Inmigración y estadísticas en el cono Sur de América. Argentina, Brasil, Chile, Uruguay (México-Montevideo, 1990).

República Argentina, Tercer censo nacional 1914, 10 vols. (Buenos Aires, 1916).

República Argentina, Memoria del Departamento General de Inmigración correspondiente al año 1890 (Buenos Aires, 1891).

Statistics Canada, 150 Years of Immigration in Canada (2016), https://www150.statcan.gc.ca/n1/pub/11-630-x/ 11-630-x2016006-eng.htm (accessed on 15 May 2018). 